\title{
The Electrical Properties of Auditory Hair Cells in the Frog Amphibian Papilla
}

\author{
Michael S. Smotherman and Peter M. Narins \\ Department of Physiological Science, The University of California, Los Angeles, California 90095-1527
}

The amphibian papilla (AP) is the principal auditory organ of the frog. Anatomical and neurophysiological evidence suggests that this hearing organ utilizes both mechanical and electrical (hair cell-based) frequency tuning mechanisms, yet relatively little is known about the electrophysiology of AP hair cells. Using the whole-cell patch-clamp technique, we have investigated the electrical properties and ionic currents of isolated hair cells along the rostrocaudal axis of the AP.

Electrical resonances were observed in the voltage response of hair cells harvested from the rostral and medial, but not caudal, regions of the AP. Two ionic currents, $I_{\mathrm{Ca}}$ and $I_{\mathrm{K}(\mathrm{Ca})}$, were observed in every hair cell; however, their amplitudes varied substantially along the epithelium. Only rostral hair cells exhibited an inactivating potassium current $\left(I_{A}\right)$, whereas an inwardly rectifying potassium current $\left(I_{K_{1}}\right)$ was identified only in caudal AP hair cells.

The frog amphibian papilla (AP) processes acoustic stimuli within a frequency range of 100 to $\sim 1250 \mathrm{~Hz}$ (Feng et al., 1975; Lewis et al., 1982a; Ronken, 1991). It is tonotopically organized (Lewis et al., 1982a), with the lowest frequencies being encoded by hair cells in the rostral patch and progressively higher frequencies being transduced more caudally. Electrical resonances in the membrane potential, which may constitute an electrical tuning mechanism (Crawford and Fettiplace, 1981), have been reported for rostral and medial hair cells of the AP in vitro, with the frequency of membrane oscillations closely overlapping the known tonotopic map of the AP (Roberts et al., 1986; Pitchford and Ashmore, 1987). Hair cell recordings from the caudal AP have not been reported. The degree to which hair cell electrophysiology is position-dependent within the frog AP offers insight into the physiology of hearing in a comparatively primitive terrestrial ear.

The frog AP is considered analogous to the primary auditory organs of fish, reptiles, and birds (Lewis and Narins, 1998). In the goldfish sacculus and the chick basilar papilla (BP), two populations of hair cells have been classified based on their position

\footnotetext{
Received Jan. 29, 1999; revised March 31, 1999; accepted April 19, 1999.

This work was supported by National Institute on Deafness and Other Communications Disorders Grant DC00222 to P.M.N. and a Hyde Fellowship from the University of California, Los Angeles Department of Physiological Science to M.S.S. We thank Drs. D. D. Simmons, C. Bertolotto, A. P. Purgue, W. M. Yamada III, E. R. Lewis, and F. Bezanilla for their technical assistance and many helpful discussions. All experiments comply with the National Institutes of Health Principles of Animal Care Publication 86-23 and all current United States laws.

Correspondence should be addressed to Peter M. Narins, Department of Physiological Science, University of California, Los Angeles, 405 Hilgard Avenue, Los Angeles, CA 90095-1527.

Copyright (C) 1999 Society for Neuroscience $\quad 0270-6474 / 99 / 190001-18 \$ 05.00 / 0$
}

Electrically tuned hair cells exhibited resonant frequencies from 50 to $375 \mathrm{~Hz}$, which correlated well with hair cell position and the tonotopic organization of the papilla. Variations in the kinetics of the outward current contribute substantially to the determination of resonant frequency. $I_{\mathrm{Ca}}$ and $I_{\mathrm{K}(\mathrm{Ca})}$ amplitudes increased with resonant frequency, reducing the membrane time constant with increasing resonant frequency. We conclude that a tonotopically organized hair cell substrate exists to support electrical tuning in the rostromedial region of the frog amphibian papilla and that the cellular mechanisms for frequency determination are very similar to those reported for another electrically tuned auditory organ, the turtle basilar papilla.

Key words: hair cells; hearing; electrical tuning; electrical resonances; frequency discrimination; frogs; Rana pipiens pipiens; amphibian papilla; calcium currents; potassium currents

within the auditory epithelium and the collection of basolateral membrane ionic currents they possess (Fuchs et al., 1988; Fuchs and Evans, 1990; Sugihara and Furukawa, 1989; Eatock et al., 1993; Murrow, 1994), and in the turtle BP hair cell, electrical properties have been shown to vary tonotopically (Crawford and Fettiplace, 1981; Art and Fettiplace, 1987; Goodman and Art, 1996a,b). In these cases, the waveform of the hair cell receptor potential is typically driven by a voltage-dependent calcium current, $I_{\mathrm{Ca}}$, and either a calcium-dependent potassium current, $I_{\mathrm{K}(\mathrm{Ca})}$, or a voltage-dependent potassium current, $I_{\mathrm{K}}$. In the turtle BP and frog sacculus (Crawford and Fettiplace, 1981; Hudspeth and Lewis, 1988; Goodman and Art, 1996a), these currents have been shown to modulate the behavior of the hair cell basolateral membrane as an electrical resonant filter. This "electrical tuning" (Crawford and Fettiplace, 1981; Art and Fettiplace, 1987; Hudspeth and Lewis, 1988) represents the contribution of the hair cell to the spectral acuity of the auditory afferent nerve fiber it contacts. Other ionic currents, such as $I_{\mathrm{A}}, I_{\mathrm{h}}$, and $I_{\mathrm{K} 1}$, have been identified in vertebrate auditory hair cells, but their functional significance remains poorly understood.

This study characterizes the electrical properties of hair cells located in the rostral, medial, and caudal regions of the leopard frog AP. We define separate rostral and caudal populations of AP hair cells based on their excitability and their compliment of ionic currents. We found that, despite the presence throughout the AP of those currents known to mediate electrical tuning $\left(I_{\mathrm{Ca}}\right.$ and $\left.I_{\mathrm{K}(\mathrm{Ca})}\right)$, electrical tuning per se was not evident throughout the entire amphibian papilla. For those hair cells exhibiting electrical resonances, we found that the distribution of resonant frequencies was consistent with a tonotopic gradation in the magnitude and kinetics of the underlying ionic currents. 


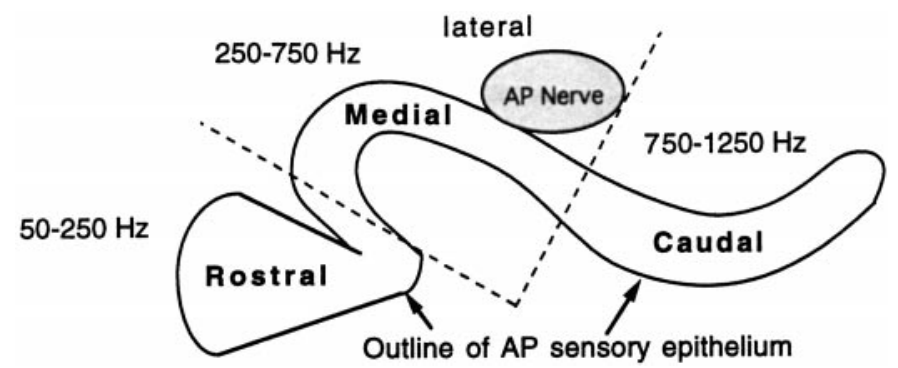

Figure 1. Map of the AP sensory epithelium. The arrangement of sensory hair cells within the chamber of the leopard frog AP is typical of most ranid frogs. The epithelium is located on the inner dorsal surface of the AP. The AP nerve branchlet exits the VIII nerve and passes around the AP ventrally and laterally before entering the dorsolateral edge of the AP. The outline of the sensory epithelium is visible through a dissecting microscope once the ventral wall of the AP chamber is excised. Dotted lines indicate where the AP was cut into three sections before hair cell dissociation. The approximate range of frequencies encoded by each section is taken from Lewis et al. (1982b).

\section{MATERIALS AND METHODS}

Dissociation of hair cells. Amphibian papillae were dissected out of pithed and decapitated adult northern leopard frogs (Rana pipiens pipiens), sectioned by eye into three parts (approximately rostral, medial, and caudal thirds) (Fig. 1), which were treated separately for $20 \mathrm{~min}$ at room temperature with $500 \mu \mathrm{g} / \mathrm{ml}$ papain (purchased from either Calbiochem, San Diego, CA, or Sigma, St. Louis, MO; both equally effective) dissolved in a dissociation solution containing (in $\mathrm{mM}$ ): $\mathrm{NaCl} \mathrm{120,} \mathrm{KCl} 5$, $\mathrm{CaCl}_{2}$ 0.1, D-glucose 3, and HEPES 10, pH 7.2. Each segment was then transferred to a dissociation solution with bovine serum albumin (500 $\mu \mathrm{g} / \mathrm{ml}$ ), replacing papain for $30-45 \mathrm{~min}$ at $<10^{\circ} \mathrm{C}$. Papillar sections were then transferred to a $0.3 \mathrm{ml}$ recording dish containing dissociation solution alone, and hair cells were gently scraped free with a tungsten needle. The hair cells settled but did not adhere firmly to the sylgard base of the recording chamber. The dissociation solution was then replaced via a continuous perfusion system with a perilymph-like (Bernard et al., 1986) standard external recording solution (Table 1). For the purpose of assessing the potentially detrimental effects of papain on hair cell electrical properties, such as those reported for frog saccular hair cells (Armstrong and Roberts, 1998), a series of experiments was performed on hair cells dissociated without the use of papain. For these experiments, hair cells were incubated in a zero calcium-added solution (rather than $0.1 \mathrm{~mm}$ calcium) buffered with $2 \mathrm{~mm}$ EGTA for a period of $40-60$ min at $<10^{\circ} \mathrm{C}$. This method resulted in a lower hair cell yield but usually provided normal-looking hair cells. We present evidence here that papain did not appear to either remove or reduce the amplitude of any ionic currents present in AP hair cells, and generally we observed no difference in the electrical properties of hair cells isolated with or without papain used as a dissociative agent.

The recording chamber was placed on the stage of an inverted microscope (Diaphot; Nikon, Tokyo, Japan) equipped with a $40 \times$ objective with phase contrast optics. The positions of the infusion and vacuum pipettes within the recording chamber were adjusted to allow for the most rapid flow while minimizing cell movement. It was generally true that after 15 min the flow speed could be substantially increased without washing away the target hair cells. Electrode tip junction potentials (13 $\mathrm{mV}$, pipette negative) were added as in Fenwick et al. (1982). A series of ionic and pharmacological agents was incorporated into the recording solution (Table 1). The exchange of recording solutions was achieved via continuous gravity perfusion of the entire recording chamber at a rate of $\sim 1 \mathrm{ml} / \mathrm{min}$. The exchange was allowed to equilibrate for at least 3 and typically $5 \mathrm{~min}$ before experiments continued and was maintained until no further change was observed in the ionic currents. Recordings were stable and consistent enough to allow several solution exchanges and reversals.

Whole-cell recordings. Currents and voltages were recorded with the conventional whole-cell tight-seal patch-clamp technique (Hamill et al., 1981). Borosilicate glass pipettes were pulled with a Narishige two-stage vertical pipette puller (model PP-83; Narishige, Tokyo, Japan) to tip diameters of $\sim 1 \mu \mathrm{m}$. Electrode resistances typically ranged from 2 to 10 $\mathrm{M} \Omega$. Series resistances $\left(R_{\mathrm{S}}\right)$ during recordings ranged from 6 to $20 \mathrm{M} \Omega$ and were compensated 60-95\% during voltage-clamp recordings using the compensation circuitry of the amplifier. Cell capacitances ranged from 4 to $20 \mathrm{pF}$. Cell capacitances and uncompensated series resistances implied a range of voltage-clamp time constants between 1.2 and 140 $\mu \mathrm{sec}$, although minor compensation-induced transients limited most experiments to $>50 \mu \mathrm{sec}$ settling times. Cell capacitance and series resistance values were read from the compensation dials of the amplifier and found to be within $5 \%$ of those calculated by fitting a single exponential function to a capacity transient and estimating $C_{\mathrm{m}}$ from the area under the curve $\left(C_{\mathrm{m}}=Q / \Delta V\right.$, where $Q$ is charge and $\Delta V$ was a $5 \mathrm{mV}$ step $)$ and $R_{\mathrm{S}}$ from $C_{\mathrm{m}}$ and the time constant of the curve $\left(R_{\mathrm{S}}=\tau / C_{\mathrm{m}}\right)$. Series resistance and cell capacitance compensation were updated continuously throughout all experiments. During long-lasting experiments, cell capacitance values taken from the amplifier typically increased $10-20 \%$ over an hour. This increase in cell capacitance has been observed previously in frog saccular hair cells and appears to be accounted for by calciumtriggered exocytosis (Parsons et al., 1994). Linear leak subtraction (realtime analog or digital) was generally not included as part of the experimental protocol. Leak substraction and corrections for voltage errors caused by $R_{\mathrm{S}}$ were performed off-line during data analysis. Typical leak conductances measured at $\pm 10 \mathrm{mV}$ at the holding potential of approximately $-60 \mathrm{mV}$ were $0.2-2.0 \mathrm{nS}$ in rostral hair cells and 3.0-8.0 $\mathrm{nS}$ in caudal hair cells. Averaging was performed for a subset of cells but not generally included in the experimental protocol. The Axopatch 200A (Axon Instruments, Foster City, CA) was used for all current-clamp and voltage-clamp experiments. For current-clamp experiments, the Axopatch 200A has separate fast and slow current-clamp modes. Oscillatory voltage responses recorded in the slow mode (which incorporates a stabilizing circuit) frequently had excessive or unrealistically high quality factors $\left(Q_{\mathrm{e}}\right.$ values $)$, suggesting the presence of a contaminating electrical feedback from the amplifier. Switching to the fast current-clamp mode eliminated any evidence of feedback and sharply reduced these $Q_{\mathrm{e}}$ values to within values typically reported for electrically tuned hair cells in the literature. Therefore, the fast current-clamp mode was the standard recording mode for studying membrane oscillations. The frequency response of both current-clamp modes was examined empirically. For a constant amplitude, swept-frequency sinusoidal input to the amplifier, the gain of the system in the fast mode was essentially flat $( \pm 2 \mathrm{~dB})$ up to $2 \mathrm{kHz}$, well above the highest characteristic frequency (CF) reported for the auditory afferents innervating the AP (Ronken, 1991). The frequency response of the amplifier in the slow current-clamp mode closely resembled that for the fast mode and exhibited a broad peak $(+3 \mathrm{~dB})$ at $\sim 1$ $\mathrm{kHz}$. Stimuli were generated and data were sampled with a 12-bit digital-to-analog and analog-to-digital converter (Digidata 1200; Axon Instruments) and controlled by the data acquisition software package pClamp 5.5 (Axon Instruments). Sampling intervals were tailored to the kinetics of the study; in general, however, voltage-clamp data were sampled at 10 or $20 \mu \mathrm{sec}$ intervals, and current-clamp data were sampled at $50-100 \mu \mathrm{sec}$ intervals. Voltage and current waveforms were low-pass filtered by the amplifier with a $2 \mathrm{kHz}$ cutoff frequency. Experiments were performed at room temperature $\left(19-20^{\circ} \mathrm{C}\right)$.

Data analysis. Current-clamp and voltage-clamp data were stored digitally and later analyzed off-line using the pClamp 5.5 Clampfit program (Axon Instruments). For determining activation and deactivation time constants, exponential curves were fit using a least-squares algorithm in pClamp. Boltzmann curves were fit using the program SigmaPlot 4.0 (Jandel Scientific, Corte Madera, CA), using the Marquardt-Levenberg algorithm. Boltzmann functions presented in this paper are of the form:

$$
I / I_{\max }=1 /\left\{1+\exp \left(\left(V_{1 / 2}-V_{\mathrm{m}}\right) / \mathrm{k}\right)\right\}
$$

for activation plots and a similar appropriately modified function for inactivation plots, where $I / I_{\max }$ is the relative current $\left(I_{\max }\right.$ is the largest amplitude tail current), $V_{1 / 2}$ is the midpoint of activation $\left(V_{1 / 2(a)}\right)$ [or inactivation $\left.\left(V_{1 / 2(\text { in })}\right)\right]$ in millivolts, $V_{\mathrm{m}}$ is the membrane potential in millivolts, and $\mathrm{k}$ (the Boltzmann constant) is a slope factor. Tail current amplitudes at step offset were estimated by fitting a single exponential function to the tail current and extrapolating back to the time of step offset. Steady-state current amplitudes were determined by averaging the last $50 \mathrm{msec}$ of a $125 \mathrm{msec}$ voltage step. Peak currents were determined by eye during computer analysis. Resonant frequency was calculated as the inverse of the mean period between successive oscillatory peaks, either at the onset or offset of a constant current pulse. We define the resonant frequency $(f)$ of a hair cell at $-53 \mathrm{mV}$, which for most cells coincides with the membrane potential at which oscillatory quality $\left(Q_{\mathrm{e}}\right)$ 


\begin{tabular}{|c|c|c|c|c|c|c|c|c|c|}
\hline & $\mathrm{CsCl}$ & $\mathrm{NaCl}$ & $\mathrm{KCl}$ & $\mathrm{CaCl}_{2}$ & $\mathrm{MgCl}_{2}$ & K-asp & glucose & HEPES & EGTA \\
\hline Internal & - & & 4 & 0.1 & 2 & 106 & 3 & 10 & 2 \\
\hline $\mathrm{CsCl}$ internal & 110 & - & - & 0.1 & 2 & - & 3 & 10 & 2 \\
\hline Reduced $\mathrm{Ca}^{2+}$ & - & 114 & 5 & 0.1 & - & - & 3 & 10 & 0.5 \\
\hline Normal & - & 110 & 5 & 4 & - & - & 3 & 10 & - \\
\hline $\mathrm{BaCl}_{2}\left(\mathrm{x}=\mathrm{BaCl}_{2}\right)$ & - & 110 & 5 & $4-x$ & - & - & 3 & 10 & - \\
\hline $\mathrm{CdCl}_{2}\left(\mathrm{x}=\mathrm{CdCl}_{2}\right)$ & - & 110 & 5 & $4-x$ & - & - & 3 & 10 & - \\
\hline $4-\mathrm{AP}(\mathrm{x}=4-\mathrm{AP})$ & - & $110-x$ & 5 & 4 & - & - & 3 & 10 & - \\
\hline TEA $(x=$ TEA $)$ & - & $110-\mathrm{x}$ & 5 & 4 & - & - & 3 & 10 & - \\
\hline
\end{tabular}

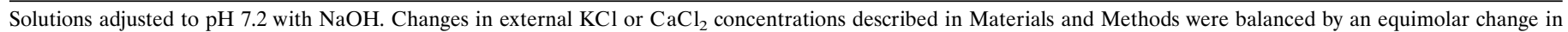

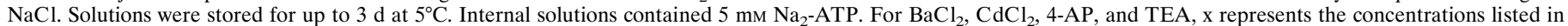
Results.

peaked and by the addition of a standing current or through adjustments in current step amplitude could be the designated potential for onset or offset oscillations. Onset or offset oscillations for a given cell will have identical resonant frequencies if recorded (separately) around a common membrane potential. $Q_{\mathrm{e}}$ was determined as by Crawford and Fettiplace (1981), using the equation $Q_{\mathrm{e}}=\left[(\pi f \tau)^{2}+0.25\right]^{1 / 2}$, where $f$ is the resonant frequency at $-53 \mathrm{mV}$ and $\tau$ is the time constant of the decay of the oscillatory peaks. A small standing current was used when necessary to raise the standing potential of a cell to $-53 \mathrm{mV}$ before the application of a depolarizing current pulse, thus allowing for offset oscillations to occur at approximately $-53 \mathrm{mV}$ in all cells for purposes of comparison. Results are presented as mean \pm SD unless otherwise noted.

\section{RESULTS}

\section{Current-clamp recordings}

\section{Resting potentials}

Based on hair cell resting potentials, two populations of hair cells are recognizable in the AP: a rostral population resting at approximately $-60 \mathrm{mV}$ and a caudal population resting at approximately $-75 \mathrm{mV}$. Hair cells were examined in external recording solutions that contained either 5 or $2 \mathrm{~mm} \mathrm{~K}^{+}$. The $2 \mathrm{~mm}\left[\mathrm{~K}^{+}\right]_{\text {ext }}$ condition is closest to the reported frog perilymph composition ( $\sim 2.5 \mathrm{~mm} \mathrm{~K}^{+}$) (Bernard et al., 1986). Medial hair cells could be divided into subgroups based on the presence or absence of an inward rectifier current $\left(I_{\mathrm{K} 1}\right)$, which has been shown in leopard frog saccular hair cells to contribute predictably to the in vitro hair cell resting potential (Holt and Eatock, 1995). In $5 \mathrm{~mm}\left[\mathrm{~K}^{+}\right]_{\mathrm{ext}}$, rostral hair cells and medial hair cells without $I_{\mathrm{K} 1}$ had resting potentials of approximately $-60 \mathrm{mV}$ [rostral, $-60.4 \pm 1.7$ (mean $\pm \mathrm{SE}$ ); $n=11$; medial, $-61.0 \pm 2.6 ; n=7$ ), which was not significantly different from cells recorded in $2 \mathrm{mM}\left[\mathrm{K}^{+}\right]_{\text {ext }}$ (rostral, $-63.3 \pm 1.5 ; n=26$; medial, $-62.5 \pm 1.0 ; n=31$ ). Caudal hair cells (all of which have $I_{\mathrm{K} 1}$ ) and medial hair cells with $I_{\mathrm{K} 1}$ had resting potentials of approximately $-70 \mathrm{mV}$ in $5 \mathrm{~mm}\left[\mathrm{~K}^{+}\right]_{\text {ext }}$ (medial with $I_{\mathrm{K} 1},-70.2 \pm 2.4 ; n=6$; caudal, $-71.7 \pm 1.0 ; n=23$ ) and approximately $-75 \mathrm{mV}$ in $2 \mathrm{~mm}\left[\mathrm{~K}^{+}\right]_{\text {ext }}$ (medial with $I_{\mathrm{K} 1}$, $-76.5 \pm 2.7 ; n=8$; caudal, $-74.6 \pm 1.9 ; n=23)$. Although the observed difference in resting potentials is reflective of a differential distribution of $I_{\mathrm{K} 1}$, there is reason to suspect that these potentials are not accurate representations of the in situ condition. Isolated hair cells may be resting at abnormally negative potentials as a result of the absence of a resting transducer current, because the transduction apparatus is known to be disrupted by zero-calcium conditions (Assad et al., 1991), such as those used in our dissociation procedure. Contradictions in in situ and in vitro resting potentials have been identified in turtle BP hair cells; although $I_{\mathrm{K} 1}$ is selectively distributed among hair cells of the turtle BP (Goodman and Art, 1996b), measurements of in

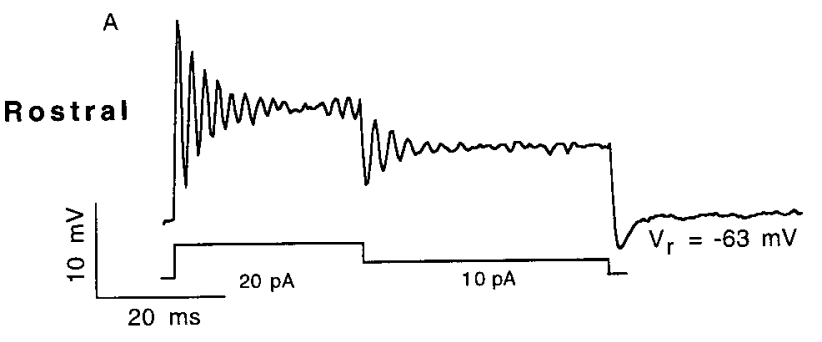

B

C

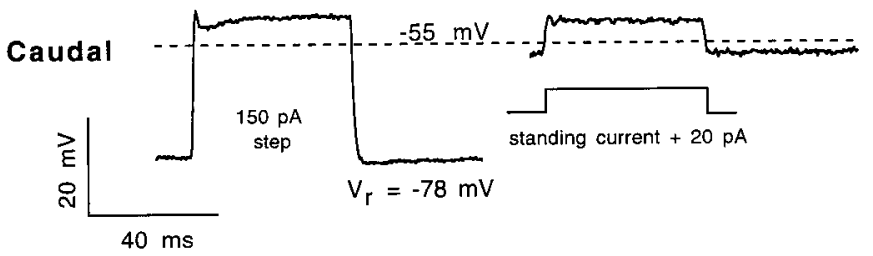

Figure 2. Variations of the voltage response of isolated AP hair cells. Current-clamp recordings of the voltage response to a depolarizing current pulse for representative rostral and caudal hair cells. $A$, Rostral hair cells always exhibited oscillatory responses, and many exhibited membrane potential oscillations at rest. Here, a rostral hair cell is first depolarized by a $20 \mathrm{pA}$ constant current, which is later reduced to a $10 \mathrm{pA}$ current before being turned off. Oscillations occurred at both the onset and transition of the current pulse because the steady-state (direct current) potential was above the threshold for $I_{\mathrm{Ca}}$. Both resonant frequency and $Q_{\mathrm{e}}$ were higher at the onset of the $20 \mathrm{pA}$ pulse than at its offset $(230$ $\mathrm{Hz} ; Q_{\mathrm{e}}$ of 13 ; steady-state voltage of $-52 \mathrm{mV}$; vs $181 \mathrm{~Hz} ; Q_{\mathrm{e}}$ of $8, V_{\mathrm{ss}}$ of $-55 \mathrm{mV}$ ). $B$, Caudal cells typically respond to depolarizing current pulses with a peak that rapidly decays to a plateau, sometimes resembling an overdamped oscillatory response. In this caudal cell, a $150 \mathrm{pA}$ stimulus applied at the zero-current potential of $-78 \mathrm{mV}$ of the cell depolarized the membrane potential to a steady-state potential of $-53 \mathrm{mV}$ (the potential at which $Q_{\mathrm{e}}$ of electrical resonances would typically be highest for oscillatory rostral hair cells). $C$, The same caudal hair cell with its membrane potential artificially maintained at approximately $-55 \mathrm{mV}$ before a $20 \mathrm{pA}$ depolarizing stimulus. Medial hair cell voltage responses could be characterized as one of these two categories (Table 2). Rostral hair cell, $9 \mathrm{pF}, 3 \mathrm{M} \Omega$ uncompensated series resistance (usr).; caudal hair cell, $4 \mathrm{pF}, 1.8 \mathrm{M} \Omega$ usr.

situ resting potentials have not uncovered comparable differences in hair cell resting potentials (Crawford and Fettiplace, 1981).

\section{Voltage responses and electrical resonances}

We examined the voltage responses (Fig. 2) of hair cells isolated from the rostral, medial, and caudal regions of the AP. We found that electrical resonances in the membrane potential could be induced by small depolarizing current pulses $(>20 \mathrm{pA})$ in all cells 
Table 2. Percent distributions of electrical resonances and supplemental potassium currents

\begin{tabular}{|c|c|c|c|c|}
\hline & $\begin{array}{l}\% \text { Oscillatory } \\
5 \mathrm{~mm}[\mathrm{~K}]_{\mathrm{ext}}\end{array}$ & $\begin{array}{l}\% \text { Oscillatory } \\
2 \mathrm{~mm}[\mathrm{~K}]_{\mathrm{ext}}\end{array}$ & $\begin{array}{l}\% \text { cells } \\
\text { with } I_{\mathrm{A}}\end{array}$ & $\begin{array}{l}\% \text { cells } \\
\text { with } I_{\mathrm{K} 1}\end{array}$ \\
\hline Rostral & $100(24)$ & $100(28)$ & $97(35)$ & $10(48)$ \\
\hline Medial & $67(22)$ & $85(40)$ & $58(36)$ & $20(70)$ \\
\hline Caudal & $0(26)$ & $31(29)$ & $16(50)$ & $90(50)$ \\
\hline
\end{tabular}

The percentage of cells studied from each region of the AP that were observed to display an oscillatory response in either 2 or $5 \mathrm{~mm}\left[\mathrm{~K}^{+}\right]_{\text {ext }}$ recording solution, compared with the percentage of cells in each case that exhibit $I_{\mathrm{A}}$ or $I_{\mathrm{K} 1}$. $(n)$ is given for each subset.

Figure 3. Voltage-dependent properties of electrical resonance. $A$, An example of electrical resonances recorded in a rostral hair cell. Depolarizing current pulses of increasing amplitude will increase the onset resonant frequency but diminish the quality factor $\left(Q_{\mathrm{e}}\right)$ of the onset oscillations. Offset oscillation frequency remains unchanged. This cell is not included in $B$ and $C . B$, As input current is increased, the steady-state membrane potential around which the onset oscillations occur is increasingly depolarized, resulting in higher frequency electrical resonance. $C$, The quality of electrical resonances $\left(Q_{\mathrm{e}}\right)$ is found to be maximal within 2 or $3 \mathrm{mV}$ of the threshold for the voltage-dependent calcium current. The hair cells represented here (same cells as in $B$ ) had maximal onset $Q_{\mathrm{e}}$ values of $\sim 20$; however, a small standing current could be used in each of the cells shown to generate continuous oscillations near the resting potential, which corresponds to an infinite $Q_{\mathrm{e}}$. Open circles, Medial hair cell, $8 \mathrm{pF}, 245 \mathrm{~Hz}$ at peak $Q_{\mathrm{e}}$ of $20 ; V_{\mathrm{h}}$ of $-54 \mathrm{mV}$; filled circles, medial hair cell, $10 \mathrm{pF}, 155 \mathrm{~Hz}$ at peak $Q_{\mathrm{e}}$ of $13.7 ; V_{\mathrm{h}}$ of $-54 \mathrm{mV}$; filled diamonds, rostral hair cell, $16 \mathrm{pF} ; 80 \mathrm{~Hz}$ at peak $Q_{\mathrm{e}}$ of $21 ; V_{\mathrm{h}}$ of $-53 \mathrm{mV}$. Curves in $B$ were drawn by eye, and curves in $C$ are interpolated.
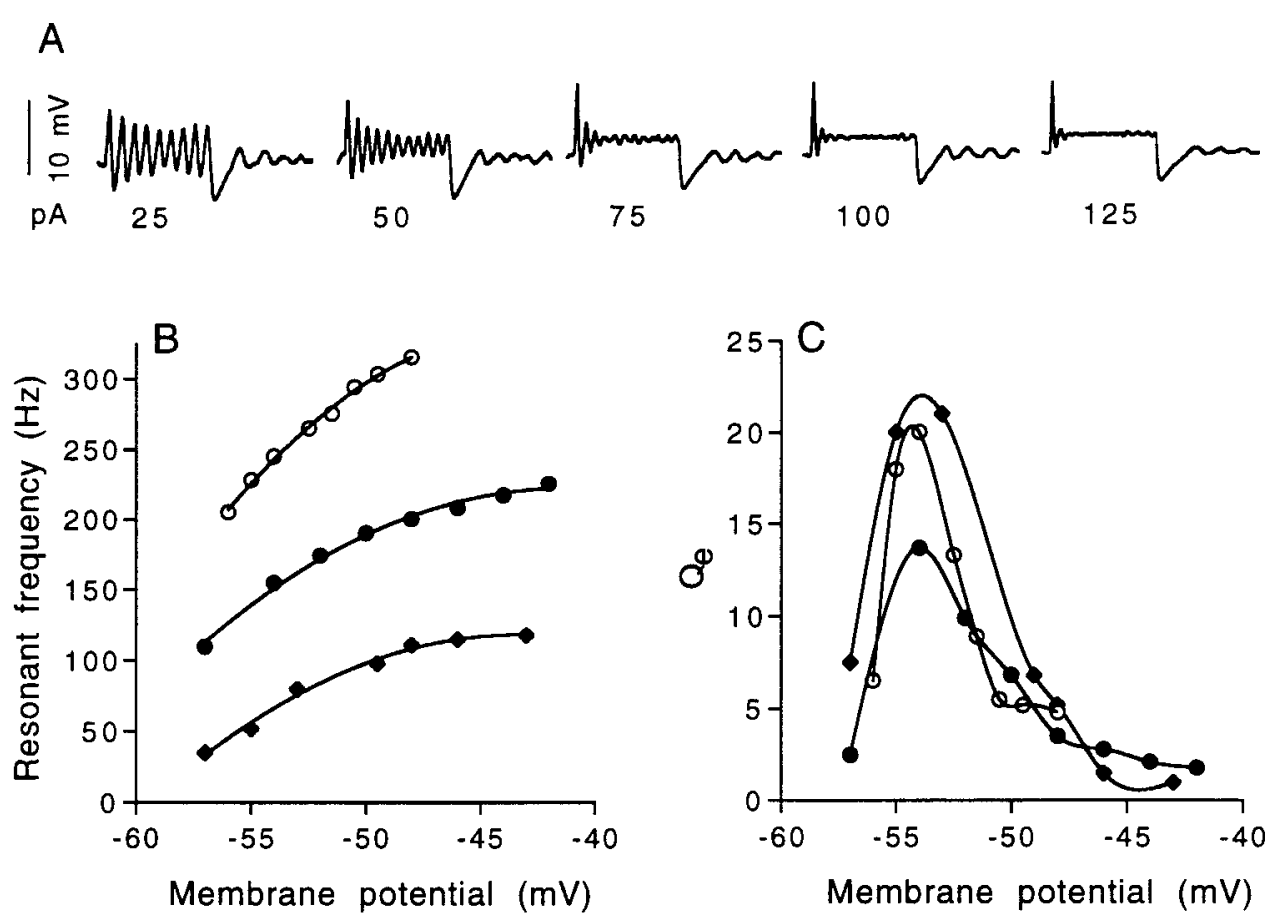

isolated from the rostral region and in approximately two-thirds of the cells located medially, whereas very few of the caudal cells responded with oscillations (Table 2). The range of resonant frequencies observed in rostral and medial hair cells was 50-375 $\mathrm{Hz}$ at $-53 \mathrm{mV}$. The few caudal hair cells that resonated (9 of 29 in $2 \mathrm{mM}\left[\mathrm{K}^{+}\right]_{\text {ext }}$ ) had resonant frequencies ranging from 160 to $270 \mathrm{~Hz}$. Electrical resonances were studied in external recording solutions that contained either 2 or $5 \mathrm{~mm}\left[\mathrm{~K}^{+}\right]_{\text {ext }}$. The quality of electrical resonances is considerably greater in the lower potassium concentration, increasing the likelihood that measurable resonances would be observed and also enhancing our ability to accurately measure the voltage-dependent properties of electrical resonance. Cells were classified as oscillatory if any depolarizing current pulse could induce voltage oscillations with a $Q_{\mathrm{e}}>1.0$ within a physiologically reasonable range of membrane potentials $( \pm 10 \mathrm{mV})$ centered around the threshold of activation for the voltage-dependent calcium current $(-55 \mathrm{mV})$. For rostral and medial hair cells, this range coincides reasonably with the typical in vitro resting potential, but for caudal cells, the resting potential is typically $15-20 \mathrm{mV}$ negative to the threshold for $g_{\mathrm{Ca}}$. To remove this difference, caudal cells were first stimulated from their zero-current membrane potential with current pulse amplitudes chosen to produce steady-state membrane potentials at or slightly positive to $-55 \mathrm{mV}$ (Fig. $2 B$ ); they were next stimulated with smaller amplitude current pulses from that holding voltage, which was artificially maintained with a standing depolarizing current (Fig. 2C). Most caudal cells responded with a brief peak depolarization that quickly decayed to a steady-state plateau, regardless of holding potential, which resembled an overdamped oscillatory voltage response. Oscillatory and nonoscillatory cell types appeared to be separated into approximately rostral and caudal halves of the AP.

Electrical resonances observed in rostromedial hair cells of the AP appeared qualitatively similar to those reported for hair cells of the bullfrog sacculus (Hudspeth and Lewis, 1988) and turtle basilar papilla (Art and Fettiplace, 1987). The frequency and quality factor $\left(Q_{\mathrm{e}}\right)$ of oscillations induced by a current pulse are voltage-sensitive. Figure 3 shows that onset oscillation frequency increases as progressively larger depolarizing current pulses were applied to the cell. This is presumably caused by the increased calcium entry with greater depolarization resulting in a more rapid opening of the calcium-dependent potassium channels. $Q_{\mathrm{e}}$ is sensitive to the amplitude of the whole-cell currents and, in particular, the ratio of the inward to the outward currents, which changes with membrane potential. As a result, $Q_{\mathrm{e}}$ is typically highest just above the threshold for $g_{\mathrm{Ca}}$ (Fig. $3 C$ ). We typically observed resting oscillations in hair cells whose zero-current membrane potential was close to or positive to the threshold for 
A
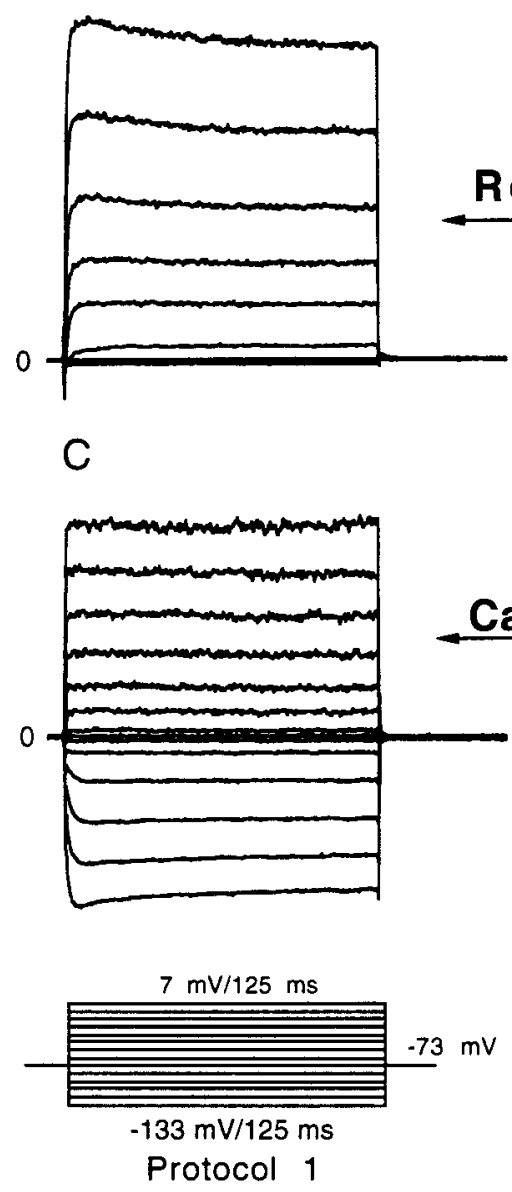

B

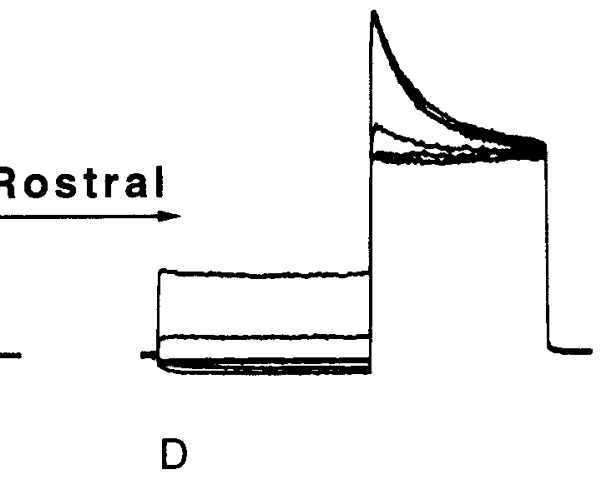

Figure 4. Voltage-dependent activation of ionic currents. Two voltage-clamp protocols were used to rapidly assess the presence of three different potassium currents $\left(I_{\mathrm{K}(\mathrm{Ca})}, I_{\mathrm{A}}\right.$, and $\left.I_{\mathrm{K} 1}\right)$ in a rostral $(A, B)$ and a caudal $(C, D)$ hair cell. In the first protocol, hair cells were voltage-clamped to potentials between -133 and $+7 \mathrm{mV}$ from a holding potential of $-73 \mathrm{mV}$, evoking both inward and outward voltagedependent currents. This could establish the presence of $I_{\mathrm{K} 1}$ and a net outward current $(A, C)$. The net outward current could be dissected by taking advantage of the different inactivating properties of $I_{\mathrm{A}}$ and $I_{\mathrm{K}(\mathrm{Ca})}$ in the second protocol $(B, D)$; hair cells were preconditioned with 2 sec steps in membrane potential ranging from -133 to $-33 \mathrm{mV}$ before a $400 \mathrm{msec}$ depolarizing step to $0 \mathrm{mV}$ (note that different sampling rates were used during the conditioning and depolarizing steps). Rostral and caudal hair cells are readily separated by the presence of either $I_{\mathrm{A}}(B)$ or $I_{\mathrm{K} 1}(C)$. An additional slowly activating inward rectifying potassium current resembling $I_{\mathrm{h}}$ (Holt and Eatock, 1995) was observed in a few rostral hair cells during prolonged hyperpolarization $(B) . A, B$, Rostral hair cell, $12 \mathrm{pF}$; $2.4 \mathrm{M} \Omega$ usr; zero-current membrane potential of $-61 \mathrm{mV} ; C, D$, caudal hair cell, $7 \mathrm{pF} ; 2.8 \mathrm{M} \Omega$ usr; zero-current membrane potential of $-78 \mathrm{mV}$.

$I_{\mathrm{Ca}}$. These "spontaneous" oscillations were also observed if the membrane potential of the cell was depolarized positive to -55 $\mathrm{mV}$ by a steady current.

\section{Characterization of the ionic currents}

\section{Overview of the ionic currents}

We identified and characterized the four largest ionic currents found in AP hair cells. $I_{\mathrm{Ca}}, I_{\mathrm{K}(\mathrm{Ca})}, I_{\mathrm{A}}$, and $I_{\mathrm{K} 1}$ were all found to be expressed in significant amplitudes in a large number of hair cells and provided sufficient grounds for the classification of two hair cell subtypes within the AP: a rostral population likely to possess $I_{\mathrm{A}}$, and a caudal population likely to possess $I_{\mathrm{K} 1}$. We encountered evidence of other ionic currents that were of substantially smaller amplitudes and/or in such limited numbers that a full characterization of them could not be included in this report. In particular, we present evidence that at least one additional voltage-dependent potassium current, $I_{\mathrm{K}}$, appears to be expressed in hair cells throughout the AP (although not apparent in every hair cell). The distribution and pharmacology of $I_{\mathrm{K}}$ remains under investigation. We also saw evidence of a second inward rectifying potassium current, $I_{\mathrm{h}}$, in a very small subset of cells. The presence of the four primary ionic currents was assessed for all three regions (rostral, medial, and caudal) of the AP from which cells were isolated. Given the apparent distribution of two hair cell subtypes, an extensive ionic and pharmacological characterization of the four ionic currents is presented for rostral and caudal hair cells, and medial hair cells included in the analysis were classified as rostral or caudal "types" based on whether they possessed $I_{\mathrm{A}}$ or $I_{\mathrm{K} 1}$. In the following sections, we will present ionic and pharmacological data comparing results derived from rostral and caudal hair cells.

\section{Oscillatory and nonoscillatory hair cells have different ionic current components}

In voltage-clamp mode, three ionic currents were identifiable under control conditions. Figure 4 demonstrates how representative rostral and caudal hair cells were tested for $I_{\mathrm{K}(\mathrm{Ca})}, I_{\mathrm{A}}$, and $I_{\mathrm{K} 1}$. All AP hair cells exhibited a noninactivating outward current, $I_{\mathrm{K}(\mathrm{Ca})}$, after depolarization to membrane potentials positive to $-55 \mathrm{mV}$ (Fig. $4 A, C$ ). For $97 \%$ of the rostral hair cells and $58 \%$ of the medial hair cells (Table 2), a hyperpolarizing prepulse before depolarization recruited an additional slowly inactivating ( $\tau_{\text {inact }}$ of $\sim 70-150 \mathrm{msec}$ ) voltage-dependent outward potassium current, $I_{\mathrm{A}}$ (Fig. $4 \mathrm{~B}$ ). Only $16 \%$ of the hair cells isolated from the caudal region possessed an inactivating outward current; most caudal hair cells responded as shown in Figure 4D. Hyperpolarizing $90 \%$ of the caudal hair cells evoked a large and fastactivating voltage-dependent current that reversed polarity at $E_{\mathrm{K}}$, becoming an inward current negative to $E_{\mathrm{K}}$. This inward potassium current, $I_{\mathrm{K} 1}$, was also found in $20 \%$ of the medial hair cells but in only $10 \%$ of the hair cells isolated from the rostral patch. Table 2 compares the distribution of oscillatory and nonoscillatory hair cells (determined as described above) with the distribution of the two voltage-dependent potassium currents $\left(I_{\mathrm{A}}\right.$ and $\left.I_{\mathrm{K} 1}\right)$. There is a strong correlation between oscillatory hair cells and the presence of $I_{\mathrm{A}}$ and between nonoscillatory hair cells and 
$I_{\mathrm{K} 1}$. However, our data also show that voltage oscillations are neither dependent on nor exclusive to either current; 4 of 34 hair cells from the medial AP that possessed $I_{\mathrm{K} 1}$ also exhibited typical electrical resonances, whereas, conversely, 9 of 34 oscillatory medial hair cells did not display $I_{\mathrm{A}}$. We can now separate hair cells into two populations in the AP based on position, resting potential, voltage response, $I_{\mathrm{A}}$ distribution, and $I_{\mathrm{K} 1}$ distribution.

\section{Pharmacological dissection of the outward current}

As stated above, the outward current could be separated into inactivating and noninactivating components. From a holding potential of $-63 \mathrm{mV}$, depolarization evoked predominantly the noninactivating outward current in both rostral and caudal hair cells. To minimize the contribution of $I_{\mathrm{A}}$ to the outward current, experiments were typically performed from the most positive holding potential just below the threshold of activation of the voltage-dependent currents, which was determined empirically during the experiment and varied between -65 and $-55 \mathrm{mV}$ among cells.

To confirm that the noninactivating outward current was a potassium current, we examined the reversal potential of the noninactivating outward current tail current. Tail current reversal potentials were measured in normal external solution composed of either 2 or $5 \mathrm{~mm}\left[\mathrm{~K}^{+}\right]_{\text {ext }}$. Tail currents were found to reverse polarity at $-76.0 \pm 6.5 \mathrm{mV}(n=3)$ in $5 \mathrm{~mm}\left[\mathrm{~K}^{+}\right]_{\text {ext }}\left(E_{\mathrm{K}}\right.$ of -81 $\mathrm{mV})$ or at $-96.0 \pm 1.6 \mathrm{mV}(n=3)$ in $2 \mathrm{mM}\left[\mathrm{K}^{+}\right]_{\text {ext }}\left(E_{\mathrm{K}}\right.$ of -104 $\mathrm{mV}$ ), supporting the assumption that the outward current is principally a potassium current.

To establish the pharmacological identity of the outward current, we examined its sensitivity to several pharmacological agents or experimental conditions known to affect potassium channels in other hair cells. Figure 5 demonstrates those results which most strongly suggest that, for both rostral and caudal hair cells, the noninactivating outward current passes through the largeconducting, BK-type, calcium-dependent potassium channel. First, the outward current was routinely sensitive to low concentrations of tetraethylammonium chloride (TEA) (Sigma). Within the range of -60 to $0 \mathrm{mV}, 10 \mathrm{~mm}$ TEA eliminated $100 \%$ of the outward current in 18 of 21 hair cells (12 rostral, 9 caudal), with a mean reduction of $99.3 \pm 0.4 \%$ (mean \pm SD), and typically revealed a voltage-dependent inward current $\left(I_{\mathrm{Ca}}\right)$. TEA also eliminated the large outward tail currents, leaving only the fast transient capacitive currents combined with the fast $I_{\mathrm{Ca}}$ tail currents. Two micromolar TEA was less effective, blocking $74.6 \pm$ $7.5 \%(n=21 ; 11$ rostral, 10 caudal $)$ of the outward current. In turtle BP hair cells, 2 mM TEA was found to block $>95 \%$ of the BK-type channels (Goodman and Art, 1996a), which leads to the suggestion that $I_{\mathrm{K}(\mathrm{Ca})}$ might not be the only steady-state outward current present in AP hair cells. Whether or not an additional outward current would be exposed by TEA depends on the relative sizes and waveforms of the inward calcium current and the remaining outward current. In Figure $6 A$, it can be seen in both a rostral and caudal hair cell that, although $10 \mathrm{~mm}$ TEA technically eliminated all outward current, an additional outward component is present with the evoked inward current. Adding 1 mM 4-AP reliably eliminated this component, revealing a waveform more typical of an uncontaminated inward calcium current. Next, we examined the sensitivity of the outward current to the scorpion toxin iberiotoxin (Ibtx) (Tocris, Ballwin, MO), which has been reported to be a highly selective BK-type potassium channel blocker (Galvez et al., 1990). In six rostral hair cells and seven caudal hair cells, $20 \mathrm{~nm}$ Ibtx eliminated all outward currents
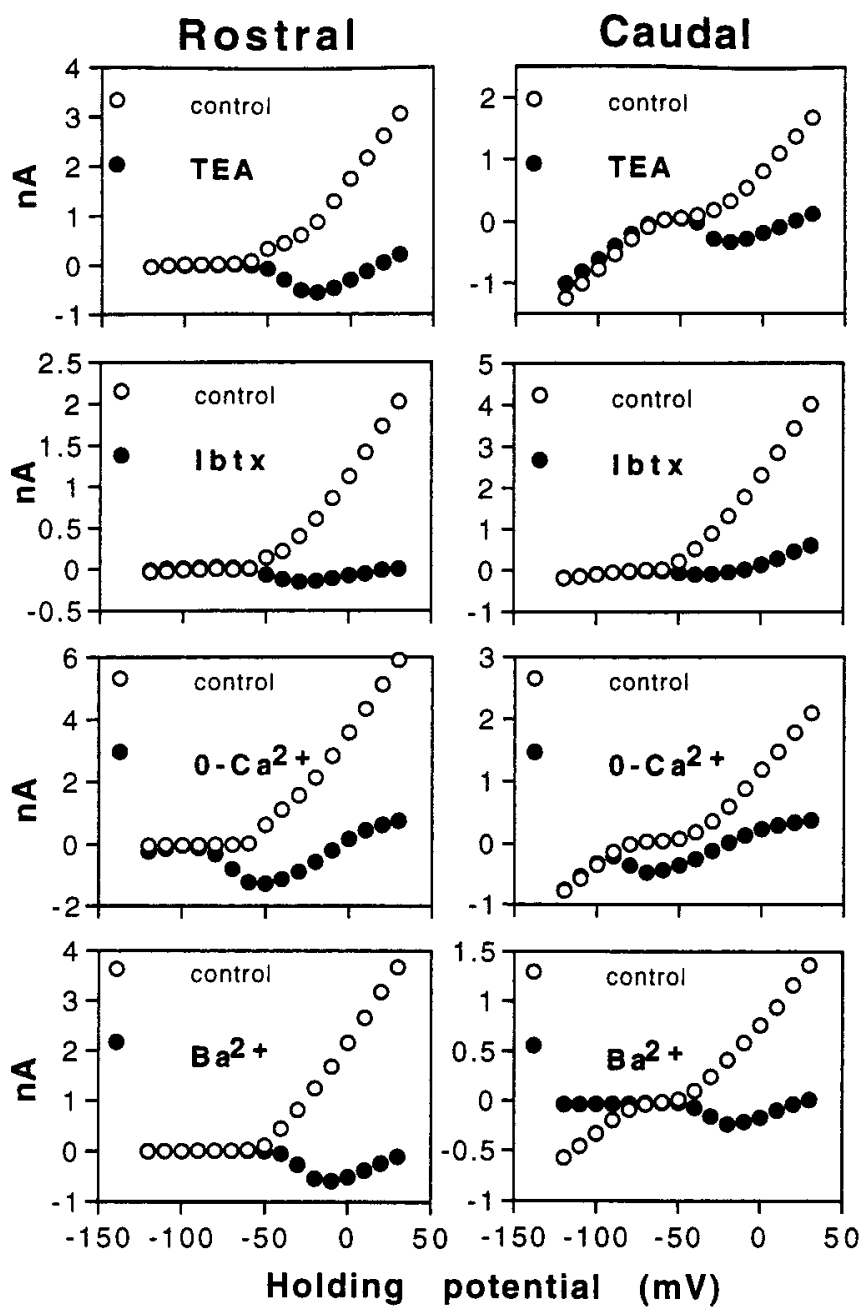

Figure 5. The outward current is predominantly $I_{\mathrm{K}(\mathrm{Ca})}$ in rostral and caudal hair cells. The sensitivity of the outward current to agents or conditions expected to block the calcium-dependent potassium current $I_{\mathrm{K}(\mathrm{Ca})}$ is presented here. TEA $(2 \mathrm{mM})$ and $20 \mathrm{nM}$ Ibtx both block the outward current and expose an inward current, $I_{\mathrm{ca}}$. Zero-calcium in the external solution or the addition of $5 \mathrm{~mm}$ barium to the external bath caused the replacement of the outward current with a large inward current. The zero-calcium condition also resulted in a hyperpolarizing shift in the threshold of the voltage-activated current. Barium is also observed to block the inward current present in caudal hair cells below $-80 \mathrm{mV}$. TEA: Rostral cell, $16 \mathrm{pF} ; 2 \mathrm{M} \Omega$ usr; $77 \mathrm{~Hz}$; caudal cell, $7.8 \mathrm{pF}$; $1.5 \mathrm{M} \Omega$ usr. Ibtx: Rostral cell, $14 \mathrm{pF} ; 3 \mathrm{M} \Omega$ usr; $90 \mathrm{~Hz}$; caudal cell, 8 pF; $2.5 \mathrm{M} \Omega$ usr. Zero-calcium: Rostral cell, $14 \mathrm{pF} ; 2.4 \mathrm{M} \Omega$ usr; $133 \mathrm{~Hz}$; caudal cell, $7.8 \mathrm{pF}$; $2.6 \mathrm{M} \Omega$ usr. Barium: rostral cell, $10.5 \mathrm{pF} ; 3.6 \mathrm{M} \Omega$ usr; $225 \mathrm{~Hz}$; caudal cell, $6.5 \mathrm{pF} ; 2.8 \mathrm{M} \Omega$ usr. All rostral cells shown here exhibited $I_{\mathrm{A}}$ but not $I_{\mathrm{K} 1}$ and conversely so for caudal cells.

between -60 and $0 \mathrm{mV}$ (Fig. 5); an inward current was revealed over this same range of membrane potentials in five of six rostral cells but in only two of seven caudal cells (Fig. 6B), again suggesting that an additional outward current is present in some hair cells. We also tested the effects of another scorpion toxin, charybdotoxin (Chtx) (Sigma) on the outward current. Chtx has also been identified as a selective blocker of BK-type potassium channels, although it may not be as selective as Ibtx (Kaczorowski et al., 1996). Chtx concentrations as low as $10 \mathrm{~nm}$ were rapidly effective in completely removing the noninactivating outward current, negative to $0 \mathrm{mV}$, in five of six rostral hair cells and four of five caudal hair cells. Like Ibtx, Chtx usually revealed an 
A

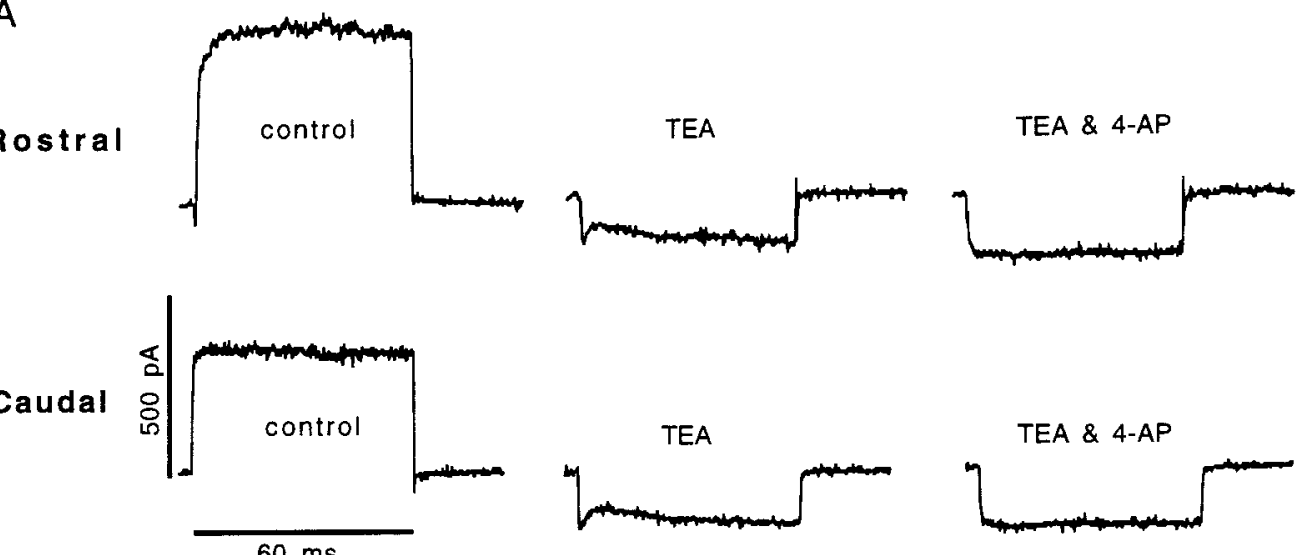

$60 \mathrm{~ms}$

B

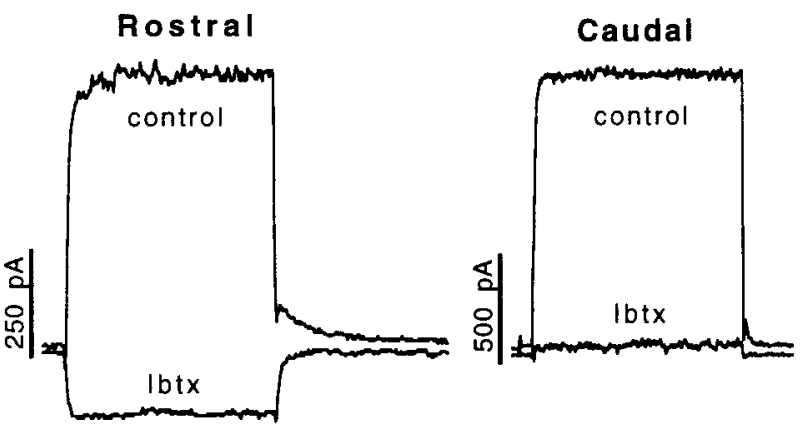

C

Rostral

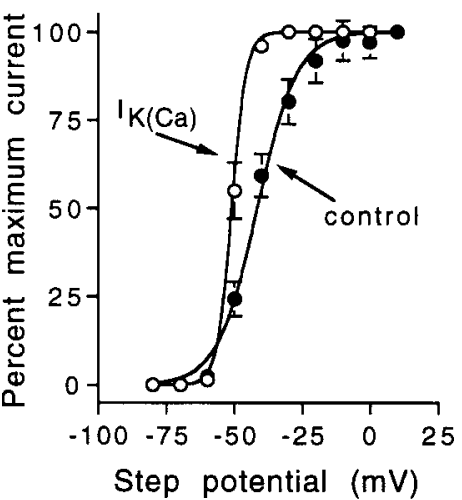

Caudal

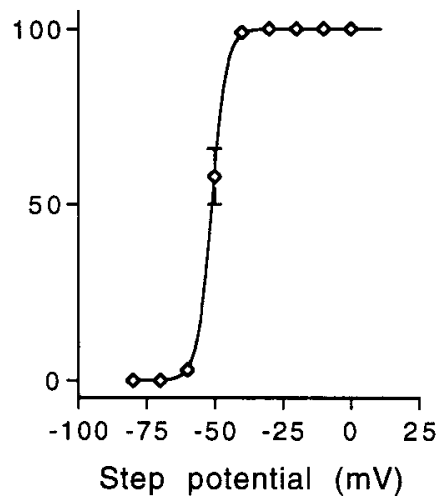

Figure 6. Dissection of the outward current. $A$, As shown in Figure 4, TEA could reliably replace the outward current with an inward current, yet evidence remains for the presence of an additional small outward current. Here, a rostral and a caudal hair cell are shown being depolarized to -20 $\mathrm{mV}$ from a holding potential of $-60 \mathrm{mV}$ (which should eliminate most $I_{\mathrm{A}}$ in rostral hair cells). In the presence of $10 \mathrm{~mm}$ TEA, a slowly inactivating component $\left(I_{\mathrm{K}}\right)$ remains visible within the inward current. This component is removed by the further addition of $1 \mathrm{~mm} 4$-AP. Although the slowly inactivating component appears pharmacologically similar to $I_{\mathrm{A}}$, it is likely to be a separate voltage-dependent potassium current (rostral cell, $12 \mathrm{pF}$; 1.8 $\mathrm{M} \Omega$ usr; caudal cell, $7 \mathrm{pF} ; 2.1 \mathrm{M} \Omega \mathrm{usr}$ ). $B$, In many other rostral hair cells, selective elimination of $I_{\mathrm{K}(\mathrm{Ca})}$ (shown here being eliminated by 20 nM Ibtx) revealed only an $I_{\mathrm{ca}}$. This rostral cell possessed a large $I_{\mathrm{A}}$ (data not shown), which does not appear to contaminate the inward current being recorded $\left(V_{\text {step }}\right.$ of $-20 \mathrm{mV} ; V_{\mathrm{h}}$ of $-60 \mathrm{mV}$ ). While recording a caudal hair cell under similar conditions, Ibtx eliminated the outward current but did not expose an inward current, which suggests that some outward current remains. $C$, Activation of the outward current was determined by measuring the peak tail current amplitude at the end of depolarizing voltage steps. Data expressed as percentages of the maximum tail current amplitude. Curves are Boltzmann functions fit to the data. For rostral hair cells, filled circles are the mean data $(n=30)$ collected from tail currents recorded in control solution from a holding potential of $-60 \mathrm{mV}$ (error bars indicate SD, shown only where error exceeds size of symbol). Open circles reflect rostral hair cell tail current measurements obtained in the presence of $1 \mathrm{mM}$ 4-AP $(n=12)$, which was used to remove any $I_{\mathrm{A}}$ or $I_{\mathrm{K}}$ contributing to the tail currents. The results show that either $I_{\mathrm{A}}$ and/or $I_{\mathrm{K}}$ are contributing to the net outward current in control solutions in rostral hair cells. For caudal hair cells, $I_{\mathrm{K} 1}$ contaminated outward tail currents in control solution, making it necessary to pharmacologically separate $I_{\mathrm{K}(\mathrm{Ca})}$ for analysis. Open circles indicate mean measurements of the TEA-sensitive or Ibtx-sensitive component of tail currents obtained for caudal hair cells. Tail currents were collected in control solution and in the presence of either TEA $(n=7)$ or Ibtx $(n=5)$, and then tails recorded in the presence of TEA-Ibtx were digitally subtracted from the control tails, which removed the tail current contributions of both $I_{\mathrm{K}}$ and $I_{\mathrm{K} 1}$ (which is 4-AP-insensitive). Boltzmann constants: control ( filled circles), $V_{1 / 2(a)}$ of -41.6; $\mathrm{k}=7.3$; rostral (open circles), $V_{1 / 2(\mathrm{a})}$ of $-50.4 ; \mathrm{k}=2.7$; caudal (open squares), $V_{1 / 2(\mathrm{a})}$ of $-51.0 ; \mathrm{k}=2.7$. 
inward current in rostral hair cells (five of five) but not in caudal hair cells (two of four). In rostral hair cells, we were able to establish that Chtx was selectively removing $I_{\mathrm{K}(\mathrm{Ca})}$ and not $I_{\mathrm{A}}$; Chtx did not alter the amplitude, kinetics, or voltage-dependence of $I_{\mathrm{A}}$.

The dependence of the noninactivating outward current on calcium was tested several ways. It was found that reducing external calcium concentrations from 4 to $0.1 \mathrm{~mm}$ eliminated $>90 \%$ of the outward current $(n=6)$. If calcium were eliminated from the external solution completely (zero-calcium added plus 2 mM EGTA), the outward current was replaced by a very large inward current in 10 of 10 rostral hair cells and 10 of 10 caudal hair cells (Fig. 5). This effect has been described previously (Art et al., 1993) and is a result of the inward calcium current being transformed in the absence of calcium into a nonselective inward current. Furthermore, it was found that if calcium were replaced with equimolar cadmium, the noninactivating outward current was completely eliminated in 10 of 11 rostral hair cells and seven of eight caudal hair cells. The A-current evoked in rostral hair cells remained in the presence of cadmium. Adding $500 \mu \mathrm{M}$ cadmium to the normal external solution could also reliably eliminate $100 \%$ of the noninactivating inward and outward currents at holding potentials between -60 and $0 \mathrm{mV}$ in rostral hair cells $(n=6)$. In caudal hair cells, cadmium did not block the inward rectifier $I_{\mathrm{K} 1}$; thus, a small outward current was recognizable between $-30 \mathrm{mV}$ and $E_{\mathrm{k}}$ in these cells. Finally, replacing external calcium with $5 \mathrm{~mm}$ barium (Fig. 5) eliminated the outward current and produced a large inward current $(\sim 2.5$ times the size of the control $I_{\mathrm{Ca}}$ ) in 12 of 12 rostral hair cells and nine of nine caudal hair cells. Barium is known to pass more readily than calcium ions through L-type calcium channels and, in doing so, generates a large inward current. Barium did not block $I_{\mathrm{A}}$ in rostral hair cells but in caudal hair cells barium blocked the inward rectifier $I_{\mathrm{K} 1}$.

The amplitude of $I_{\mathrm{K}(\mathrm{Ca})}$ appeared to vary substantially both between rostral and caudal hair cells and between hair cells within each region. We observed a large difference in the mean amplitude of $I_{\mathrm{K}(\mathrm{Ca})}$ between rostral and caudal hair cells; rostral cells possessed a mean $I_{\mathrm{K}(\mathrm{Ca})}$ at $-20 \mathrm{mV}$ of $2.73 \pm 1.10 \mathrm{nA}$ (corrected for inward current amplitudes measured in TEA-4AP), whereas mean values for caudal hair cells were much lower at $0.82 \pm 0.12 \mathrm{nA}$. The range of current amplitudes observed in rostromedial hair cells $(0.5-4.5 \mathrm{nA}$ at $-20 \mathrm{mV})$ fully encompassed the much lower range of outward current amplitudes in caudal hair cells $(0.4-2.2 \mathrm{nA})$. We will show below that the amplitude of the outward current was closely coupled to resonant frequency in rostral and medial hair cells, but we found no consistent relationship between outward current amplitude and cell size in the caudal AP.

The activation range of the noninactivating outward current was assessed for rostral and caudal hair cells by examining peak tail current amplitudes. In Figure $6 C$, the filled circles represent the mean $(n=30)$ tail current amplitudes after depolarizing steps that were initiated from an interpulse holding potential of -60 $\mathrm{mV}$. Open circles represent the same data collected for 12 rostral hair cells but in the presence of 4-AP. Removal of the 4-APsensitive component of the tail currents caused the Boltzmann curve to steepen. Tail currents measured in the presence of 4-AP should specifically reflect the activation of $I_{\mathrm{K}(\mathrm{Ca})}$ : for this set of tail currents, $V_{1 / 2 \text { (a) }}$ of $-50.4 \pm 6.0 \mathrm{mV}$; the Boltzmann constant $\mathrm{k}=2.7$ (and for the control set, $V_{1 / 2 \text { (a) }}$ of $-41.6 \pm 3.5 \mathrm{mV} ; \mathrm{k}=$ 7.3), which are similar to values reported for $I_{\mathrm{K}(\mathrm{Ca})}$ in other hair cells (Art and Fettiplace, 1987; Hudspeth and Lewis, 1988). The observed shift in the Boltzmann curve correlates with a $12 \%$ decline in the mean $I_{\max }$ (comparing the 4-AP mean to the control mean). The 4-AP-sensitive component of the tail current may reflect the contaminating presence of $I_{\mathrm{A}}$ (because the holding potential used falls within the region of overlapping activation and inactivation ranges of $I_{\mathrm{A}}$, although $>95 \%$ of $I_{\mathrm{A}}$ should be inactive from a $-60 \mathrm{mV}$ holding potential), or it may reveal the presence of an additional 4-AP-sensitive potassium current. For caudal hair cells, tail currents are contaminated by the activation of the inward rectifier $I_{\mathrm{K} 1}$ after repolarization of the membrane potential. To eliminate this effect, we recorded outward current tail currents in control solution and then in the presence of either TEA or Ibtx. Tail currents recorded in the presence of TEA or Ibtx were then digitally subtracted from the control tail currents, and thereby revealed the TEA-sensitive (or Ibtx-sensitive) tail currents. We were able to estimate tail current amplitudes using this method, and the open squares in Figure $6 D$ represent the means of a total 12 caudal hair cells analyzed in this way. The results show that the primary components of the outward current in both rostral and caudal hair cells follow identical voltagedependent activation patterns.

For both rostral and caudal hair cells, the noninactivating outward current appears to pass primarily through BK-type calcium-dependent potassium channels. It was generally true that an additional outward component was observed in both steadystate and tail current measurements. Although some of this may by accredited to A-current contamination, there are multiple lines of evidence to support the presence of a second voltagedependent potassium current in some cells, active from normal hair cell resting potentials, which we will refer to for now as $I_{\mathrm{K}}$. In particular, the TEA-insensitive outward current observed in caudal cells not having an appreciable A-current and the effect of 4-AP on tail currents, which (because of the length of the depolarizing step) should not have included significant A-current, imply the presence of an $I_{\mathrm{K}}$ in both rostral and caudal hair cells. Furthermore, an $I_{\mathrm{K}}$ was recently reported in frog saccular hair cells (Armstrong and Roberts, 1998) and frog BP hair cells (Smotherman and Narins, 1999), both of which share a very similar physiology with AP hair cells. We have not completed our investigation of this current, and we have not definitively separated this current from $I_{\mathrm{A}}$, but if $I_{\mathrm{K}}$ does exist in AP hair cells, it does not appear to be restricted to either rostral or caudal hair cells.

\section{Characterization of $I_{A}$}

In rostral hair cells, the inactivating component of the outward current (Figs. 4B,7A) was sensitive to low concentrations of 4-AP. The prepulse protocol (Fig. 4, Protocol 2) was used to recruit and measure the amplitude and voltage-dependence of the A-current before the addition of $1 \mathrm{~mm} 4$-AP. The inactivating component of the outward current was then routinely eliminated (95.8 $\pm 0.6 \% ; n=15)$ by the presence of $1 \mathrm{~mm} \mathrm{4-AP}$ added externally. From a holding potential of $-120 \mathrm{mV}$, the combined addition of $10 \mathrm{~mm}$ TEA and $1 \mathrm{~mm} 4-\mathrm{AP}$ was sufficient to completely remove all outward currents, exposing the noninactivating inward calcium current. The effect of $10 \mathrm{~mm}$ TEA on $I_{\mathrm{A}}$ was a reduction in the peak amplitude of the inactivating component of $8.5 \pm 6.5 \%(n=10$; mean peak amplitude was $448 \mathrm{pA}$ at $0 \mathrm{mV})$.

Some studies of the A-current were performed using $\mathrm{CdCl}_{2}$ as a blocker of both the inward calcium current and the outward calcium-dependent potassium current. Figure $7 A$ presents an ex- 
A

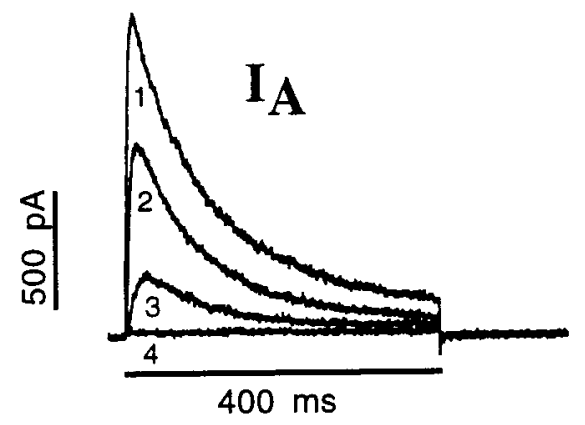

B

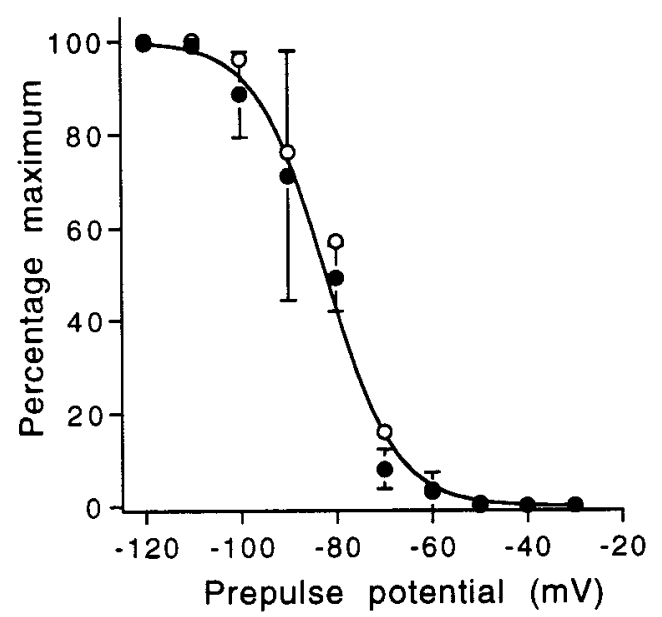

C

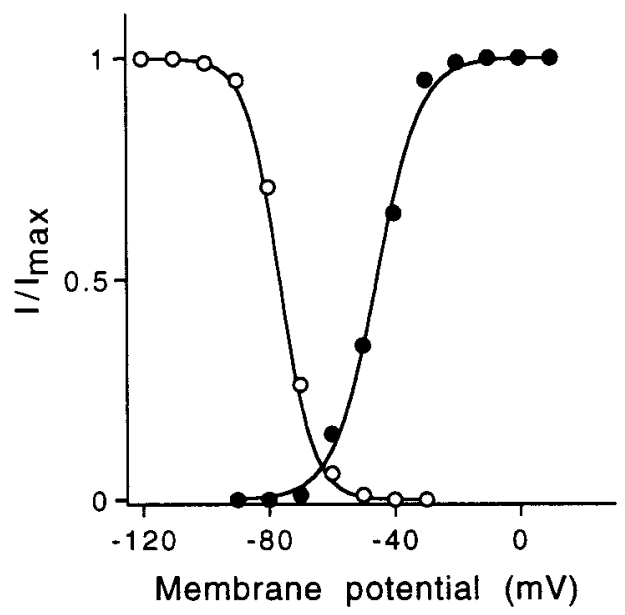

Figure 7. Isolation, activation, and inactivation of $I_{\mathrm{A}}$. Although $I_{\mathrm{K}(\mathrm{Ca})}$ could be blocked by several methods, external cadmium was exceptionally useful for exposing $I_{\mathrm{A}}$ because it eliminated both $I_{\mathrm{K}(\mathrm{Ca})}$ and $I_{\mathrm{Ca}}$. As described in Results, external cadmium also shifted the activation and inactivation ranges of $I_{\mathrm{A}}$ by approximately $+40 \mathrm{mV}$, thereby removing the need for hyperpolarizing steps before depolarization and activation of $I_{\mathrm{A}}$. In $A$, an example of $I_{\mathrm{A}}$ isolated by the application of cadmium is presented. Here, $I_{\mathrm{A}}$ is evoked by steps to $-30 \mathrm{mV}(4),-10 \mathrm{mV}(3),+10 \mathrm{mV}$ (2), and $+30 \mathrm{mV}$ (1), from a holding potential of $-73 \mathrm{mV}$. B, Percent maximum A-current amplitude at $0 \mathrm{mV}$ was measured after a series of hyperpolarizing prepulses ( $x$-axis) for 2 sec. Filled circles represent the average of 15 cells (errors bars reflect SD) studied in control solution, and the data were fit with the Boltzmann function shown (Eq. 1); $V_{1 / 2 \text { (in) }}$ of $-81.2 \mathrm{mV} ; \mathrm{k}=7.2$. Open circles represent the average of five cells studied in the presence of Chtx. For a Boltzmann fit to this set of data, $V_{1 / 2(\mathrm{in})}$ of $-79.7 \mathrm{mV} ; \mathrm{k}=6.8$, supporting the assumption that Chtx has no effect on ample of $I_{\mathrm{A}}$ recorded in $2 \mathrm{~mm}$ cadmium. It was discovered that, although this was a useful method for isolating $I_{\mathrm{A}}$, cadmium caused a large (approximately $+40 \mathrm{mV}$ ) shift in all of the voltagedependent properties of $I_{\mathrm{A}}$. Cadmium produced a reversible depolarization of the $V_{1 / 2(\text { in) }}$ from -78.6 to $-40.4 \mathrm{mV}$ (Boltzmann fits to mean of five cells studied in both control and $2 \mathrm{~mm}$ $\mathrm{Cd}^{2+}$ ), and caused a concomitant shift of similar magnitude in the activation threshold for both the steady-state currents and peak tail currents. Recordings in cadmium did not appear to change the time course of activation, inactivation, or deactivation of the A-current.

Figure $7 B$ illustrates the mean inactivation curves for $I_{\mathrm{A}}$ recorded in control solution and in Chtx. The $V_{1 / 2 \text { (in) }}$ for control cells (mean data set, $n=15$ ) was $-81.2 \mathrm{mV}$, which is very close to the initial value reported by Hudspeth and Lewis (1988) in bullfrog saccular hair cells. We saw no systematic shift in the inactivation range of $I_{\mathrm{A}}$ during the course of our experiments. The mean threshold of activation for $I_{\mathrm{A}}$ as determined by eye from Boltzmann curves fit to peak tail currents recorded in Chtx was $-61.2 \pm 3.5 \mathrm{mV}(n=15)$; the mean $V_{1 / 2(a)}$ for the same set was $-44.7 \pm 3.0 \mathrm{mV}(n=15)$. Figure $7 C$ illustrates the activation and inactivation range for a single cell studied in the presence of Chtx $(1 \mu \mathrm{M})$. At approximately the measured resting potential of rostral hair cells, there is a narrow region of overlap between the activation and inactivation range of $I_{\mathrm{A}}$, suggesting that this current could contribute to both the resting potential and the receptor potential of the cell. The time courses of activation $\left(T_{\text {peak }}\right.$; time to peak) and inactivation $\left(\tau_{\text {inact }}\right)$ were voltage-sensitive, both becoming faster with increasing depolarization. $T_{\text {peak }}$ varied only slightly between cells, typically ranging between 18 and $23 \mathrm{msec}$ at $-20 \mathrm{mV}(19.7 \pm 4.5 \mathrm{~ms} ; n=28)$. At $-20 \mathrm{mV}, \tau_{\text {inact }}$ was observed to vary between 70 and $120 \mathrm{msec}$ among all cells studied, with a mean of $110.3 \pm 27.2 \mathrm{msec}(n=28)$.

An analysis of tail current amplitudes confirmed that $I_{\mathrm{A}}$ is a potassium current. Tail currents of $I_{\mathrm{A}}$ were analyzed in the presence of Chtx $(n=2)$ or $\mathrm{CdCl}_{2}(n=2)$. In $5 \mathrm{~mm}$ external potassium, the mean tail current reversal potential was $-75.2 \pm$ $2.3 \mathrm{mV}(n=4)$.

\section{The calcium current}

Most of the analysis of $I_{\mathrm{Ca}}$ kinetics and voltage dependence presented here was performed with a $110 \mathrm{~mm}$ CsCl-based internal pipette solution (Table 1), which always revealed a noninactivating inward current after depolarization of the cell. For both rostral and caudal hair cells, the mean threshold of activation (estimated by eye from $I-V$ curves) was $-55.8 \pm 0.8 \mathrm{mV}(n=59)$; the mean $V_{1 / 2 \text { (a) }}$ was $-42.2 \pm 2.8 \mathrm{mV}$ (Boltzmann fits to peak tail current measurements, $n=9$ ), and the peak inward current occurred at a potential of $-23.0 \pm 1.2 \mathrm{mV}(n=59)$. The time course of activation was fit with a single exponential curve over the first $5 \mathrm{msec}$ of the record. The activation time constant at -23 $\mathrm{mV}$ varied between 0.5 and $1.1 \mathrm{msec}$. Deactivating tail currents

\section{$\leftarrow$}

the voltage dependence of $I_{\mathrm{A}}$. Error bars and Boltzmann curve not shown for Chtx data. C, Activation ( filled circles) and inactivation (open circles) curves for a cell studied in the presence of Chtx, which completely blocked $I_{\mathrm{K}(\mathrm{Ca})}$. Inactivation was determined as described in Figure 3. Activation was determined from peak tail currents at $-60 \mathrm{mV}$ after brief depolarizing steps that ended at or shortly after $I_{\mathrm{A}}$ had reached its peak outward current. Boltzmann curves fit to both activation and inactivation data sets; for activation, $V_{1 / 2(a)}$ of $-45.6 \mathrm{mV} ; \mathrm{k}=7$; and for inactivation, $V_{1 / 2(\mathrm{in})}$ of $-76.5 \mathrm{mV} ; \mathrm{k}=5.2$. Rostral hair cell, $11 \mathrm{pF} ; 2.2 \mathrm{M} \Omega$ usr. 
Figure 8 . Ionic sensitivity and pharmacology of the inward calcium current. $A$, The inward current revealed by a $\mathrm{CsCl}$ internal pipette solution could be modulated by changes in $\left[\mathrm{Ca}^{+2}\right]_{\text {ext }}$. The control solution used in most experiments contained $4 \mathrm{~mm}$ calcium. Increasing the external concentration to $20 \mathrm{~mm}$ caused an approximately fourfold increase in the size of the inward current. In contrast, the addition of $50 \mu \mathrm{M}$ cadmium to the control solution caused a rapid but reversible block of the inward current. $B, I-V$ curve derived for the same cell in 4 and $20 \mathrm{~mm}$ $\left[\mathrm{Ca}^{+2}\right]_{\text {ext }}$, from a holding potential of $-73 \mathrm{mV}$. Oscillatory medial hair cell, $11 \mathrm{pF} ; 9 \mathrm{M} \Omega ; 80 \%$ src. $C$, Bay K $8644(5 \mu \mathrm{M})$, an L-type calcium channel agonist, caused an increase in the steady-state and peak tail-current amplitudes, which is attributed to an extension in the single channel mean open time. The tail current becomes substantially slower with Bay K 8644 . This drug not only increases the steady-state amplitude over the entire voltage range $(D)$ but produces a much steeper activation slope (the peak inward current is shifted from -23 to -48 $\mathrm{mV}$ ) and appears to hyperpolarize the threshold of activation. Medial hair cell, $10 \mathrm{pF} ; 16 \mathrm{M} \Omega$; $80 \%$ series resistance compensation (src). $E$, The mean steady-state $I-V$ curves for rostral $(n=10)$ and caudal $(n=10)$ hair cells recorded in zero external calcium. Error bars are shown where they exceed the size of the symbols. The steady-state reversal potentials were -8 (rostral) and $-19 \mathrm{mV}$ (caudal). $F$, The mean steady-state $I-V$ curves for rostral $(n=12)$ and caudal $(n=$ 9) hair cells recorded in $5 \mathrm{~mm}$ external barium. The steady-state reversal potentials were +36 (rostral) and $+25 \mathrm{mV}$ (caudal).
A
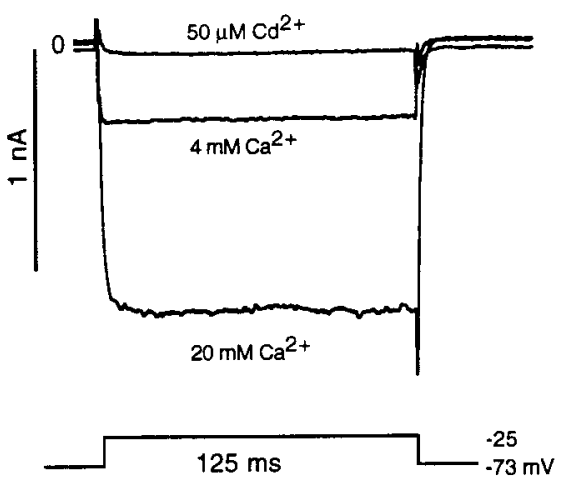

C

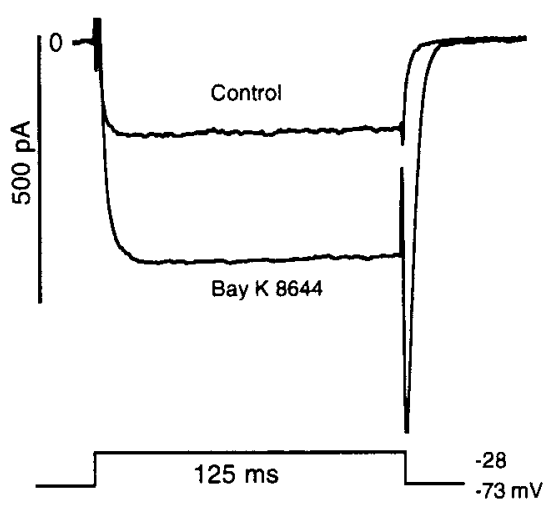

B

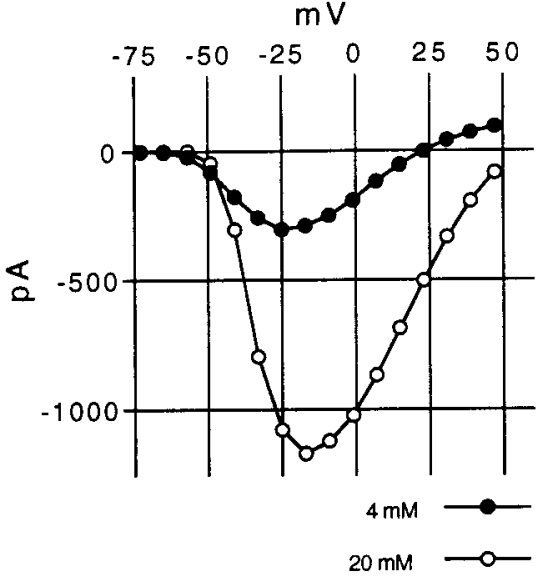

D

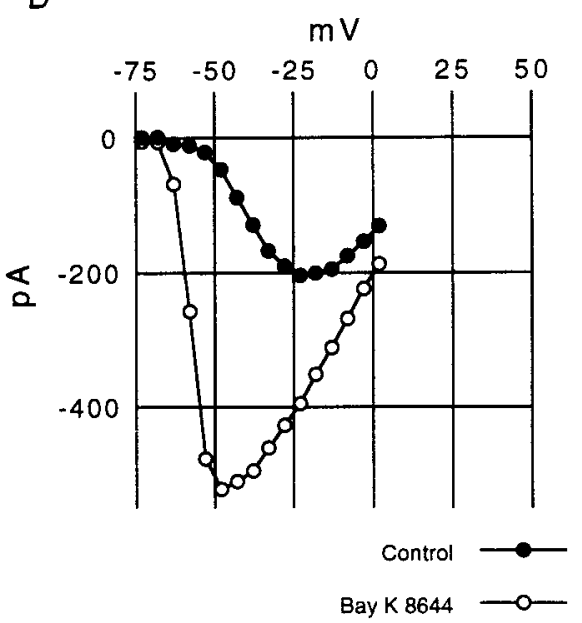

F
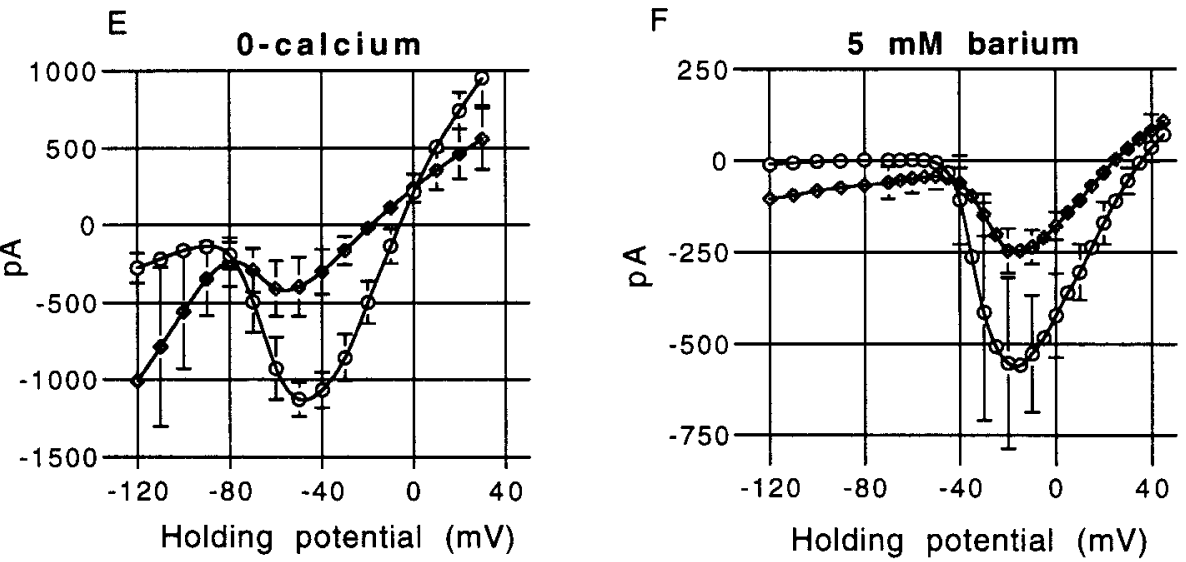

Holding potential $(\mathrm{mV})$

$$
\text { Rostral } \quad 0 \quad 0 \quad \text { Caudal }
$$

were best fit with a double exponential curve (Zidanic and Fuchs, 1995), with the fast component (accounting for most of the inward tail current) having a time constant between 0.2 and 0.5 msec (approaching the limitations of the voltage clamp). Measuring the inward current $I-V$ curve in caudal hair cells was complicated by the presence of the inward rectifying potassium conductance $I_{\mathrm{K} 1}$, which contributed a sizable inward current at the standard holding potential $(-60 \mathrm{mV})$ when the cell was infused with $\mathrm{Cs}^{+}$. For these cells, external barium (replacing calcium) was used to establish that the inward current in caudal hair cells exhibited a voltage dependence and range of kinetic properties essentially identical to rostral hair cells under otherwise similar recording conditions.

For both rostral $(n=18)$ and caudal $(n=15)$ hair cells, the amplitude of the inward current was sensitive to external calcium concentrations (Fig. $8 A$ ). The inward current was rapidly blocked by micromolar concentrations of cadmium (Fig. $8 A$ ). These channels passed barium ions more readily than calcium ions (rostral, 
$n=12$; caudal, $n=9$ ) (Fig. $8 F$ ); currents recorded in $5 \mathrm{~mm}$ $\left[\mathrm{Ba}^{2+}\right]_{\text {ext }}$ were approximately 2.5 times greater than those recorded in $4 \mathrm{~mm}\left[\mathrm{Ca}^{2+}\right]_{\text {ext }}$. Calcium and barium currents exhibited a steady decline in amplitude, typically decreasing by at least $20 \%$ over the course of a 15 min experiment. As mentioned above, a zero-calcium external solution resulted in a large nonselective inward current appearing in place of the inward calcium current. The threshold of activation for this current was $\sim 20 \mathrm{mV}$ negative to the threshold of $I_{\mathrm{Ca}}$, and the steady-state current reversed polarity close to $0 \mathrm{mV}$. These features are consistent with the effects of low calcium reported by Art et al. (1993) on L-type calcium channels in turtle BP hair cells in which it was shown that, in the absence of calcium, these calcium channels become nonselective ion channels and their activation threshold is hyperpolarized. We applied the calcium channel antagonist nifedipine (50 $\mu \mathrm{M}$ ) while recording the nonselective inward current in five rostral hair cells and observed a mean blockage of $65 \pm 20 \%$ of the peak inward current. This partial blockage is consistent with the effects of nifedipine on calcium currents in other hair cells (Fuchs et al., 1990). These observations support the assumption that this is the L-type calcium current commonly reported in other auditory hair cells (Art and Fettiplace, 1987; Hudspeth and Lewis, 1988; Zidanic and Fuchs, 1995). To further test this assumption, we applied the L-type calcium channel agonist Bay K 8644 (Sigma) to both rostral and caudal hair cells $(n=3$ and 2, respectively). In every case, Bay K $8644(0.1 \mu \mathrm{M})$ caused a pronounced increase in the steady-state amplitude of the inward current $(135 \pm 22 \% ; n=5)$. As can be seen in Figure $8 C$, the corresponding peak tail current amplitude is enlarged and relaxation of the tail current is prolonged, which is consistent with the reported action of Bay K 8644 on L-type calcium channels (Fuchs et al., 1990). Furthermore, it can be observed that Bay K 8644 changes the shape of the calcium $I-V$ curve (Fig. 8 , compare $B$, $D$ ), producing a much narrower voltage activation range and hyperpolarizing the potential at which the peak inward current occurs by almost $25 \mathrm{mV}$. We conclude that, for rostral and caudal hair cells, the inward current activated by depolarization is predominantly an L-type calcium current. We did not test for the presence of other calcium channels, such as the N-type channels reported in frog saccular hair cells (Su et al., 1995). Furthermore, it should be noted that, because of their smaller size and greater sensitivity to the detrimental effects of patch-clamp recording, the pharmacology of caudal hair cell calcium currents is less certain than that of rostral hair cells. Yet, the essentially identical kinetics, voltage dependence, and ionic selectivities of the calcium currents in rostral and caudal hair cells support the conclusions that these currents are at least very similar for all AP hair cells.

Although the calcium current could be exposed either through the infusion of cesium or the external application of $10 \mathrm{~mm}$ TEA together with $1 \mathrm{~mm} 4-\mathrm{AP}$, it was found that there was a substantial difference in the amplitude of the mean inward current generated by the two methods. For example, for rostral hair cells, the mean inward current recorded at $-20 \mathrm{mV}$ using an internal cesium pipette solution was $328 \pm 76 \mathrm{pA}$ (mean $\pm \mathrm{SD} ; n=21)$, with a mean current density of $25 \pm 6 \mathrm{pA} / \mathrm{pF}$, whereas using TEA-4-AP with a standard internal solution produced mean inward currents of $430 \pm 85 \mathrm{pA}(n=14)$, with a mean current density of $33 \pm 6$ $\mathrm{pA} / \mathrm{pF}$. There appeared to be a difference in the means and overall range of inward currents observed between rostral and caudal hair cells. Using TEA-4-AP to expose the inward current, the mean peak inward current for caudal hair cells was $120 \pm 34$ pA $(n=9)$ and ranged from 60 to $180 \mathrm{pA}$. For rostral cells, the mean peak inward current was $430 \pm 85 \mathrm{pA}(n=14)$ and ranged from 160 to $634 \mathrm{pA}$. Calcium currents measured in cesium-loaded hair cells also follow this trend; for rostral hair cells, the mean peak inward current was $350 \pm 103 \mathrm{pA}(n=12)$, whereas for caudal hair cells, it was $110 \pm 43 \mathrm{pA}(n=9) . I_{\mathrm{Ba}}$ in caudal hair cells was $314 \pm 150 \mathrm{pA}$ ( $n=9$; ranging from 134 to $600 \mathrm{pA})$, which was approximately half the mean value found in rostral hair cells, $625 \pm 340 \mathrm{pA}$ ( $n=9$; ranging from $400 \mathrm{pA}$ to $1.1 \mathrm{nA})$. It remains possible that sampling error contributed to these differences and that subregional variations in current amplitudes are the source of the observed amplitude variations. As we will show below, current amplitudes were seen to vary with position (and frequency) within the rostromedial region of the AP, but we have not yet uncovered evidence of position-related gradients in the amplitudes of $I_{\mathrm{Ca}}$ and $I_{\mathrm{K}(\mathrm{Ca})}$ in caudal hair cells.

Calcium current reversal potentials (Fig. 8), were consistently negative to the presumptive $E_{\mathrm{Ca}}(>+80 \mathrm{mV})$ but were similar ( $\pm 10 \mathrm{mV}$ and spanning the same range) for both $\mathrm{Cs}$-exposed and TEA-4-AP-exposed inward currents. These reversal potentials, typically $25-30 \mathrm{mV}$ in $4 \mathrm{~mm}\left[\mathrm{Ca}^{2+}\right]_{\text {ext }}$, are comparable with those reported in chick hair cells (Fuchs et al., 1990) and frog saccular hair cells (Hudspeth and Lewis, 1988) under similar recording conditions. Barium currents, recorded in $5 \mathrm{~mm}\left[\mathrm{Ba}^{2+}\right]_{\text {ext }}$ plus 1 $\mathrm{mm}$ 4-AP, exhibited reversal potentials in the range of $20-40 \mathrm{mV}$, but the mean reversal potential for caudal cells was $11 \mathrm{mV}$ more negative than the mean for rostral hair cells (Fig. $8 F$ ). This pattern was also observed regarding the reversal potential of the nonselective inward current recorded in zero-calcium; the mean reversal potential for caudal hair cells was $11 \mathrm{mV}$ more negative than the mean for rostral hair cells. Although we have not yet accounted for this experimental difference, one likely explanation might be the contaminating presence of an additional $I_{\mathrm{K}}$, which, although small, may contribute to a larger percentage of the total membrane conductance in caudal hair cells than in rostral hair cells.

\section{The inward rectifying $\mathrm{K}^{+}$current}

As described above, hair cells isolated from the caudal half of the AP are likely to possess the inward rectifying potassium current $I_{\mathrm{K} 1}$ (Figs. 4C, 9). This current begins to activate below a threshold of approximately $-30 \mathrm{mV}$ (derived from fit by eye to steady-state $I-V$ curves recorded in external cadmium; $n=7$ ), and the steadystate current has a reversal potential near $E_{\mathrm{K}}$ (Fig. 9B). The speed of activation increases with increasing hyperpolarization, and the current exhibits mild inactivation with hyperpolarizations to potentials negative to $-120 \mathrm{mV}$. The time course of activation could be fit by a single exponential curve. The mean activation time constant at $-100 \mathrm{mV}$ was $5.6 \pm 1.1 \mathrm{msec}(n=28$; recorded in 5 $\mathrm{mM}\left[\mathrm{K}^{+}\right]_{\text {ext }}$ ). After return to a holding potential of $-50 \mathrm{mV}$ (in $4 \mathrm{mM} \mathrm{CdCl}_{2}$ ), tail currents were best fit with a double exponential, with fast $(0.38 \pm 0.10 \mathrm{msec} ; n=7)$ and slow $(2.45 \pm 0.35$ msec) time constants. The reversal potential of the steady-state current closely followed $E_{\mathrm{K}}$; in $2 \mathrm{~mm}\left[\mathrm{~K}^{+}\right]_{\text {ext }}$, the steady-state current was zero at a mean potential of $-97.3 \pm 4.2 \mathrm{mV}(n=8)$, whereas in $5 \mathrm{~mm}\left[\mathrm{~K}^{+}\right]_{\text {ext }}$, the steady-state current was zero at a mean potential of $-76.5 \pm 2.5 \mathrm{mV}(n=28) . I_{\mathrm{K} 1}$ was insensitive to external cadmium but was highly sensitive to barium (in control solution the mean $I_{\mathrm{K} 1}$ for caudal cells at $-120 \mathrm{mV}$ was $1.3 \pm 0.3$ $\mathrm{nA} ; n=22$ ) (Fig. $8 F)$. Barium $(500 \mu \mathrm{M})$ applied externally resulted in a rapid and complete block of $I_{\mathrm{K} 1}$. Based on its kinetics, its voltage dependence, and its sensitivity to barium but not cadmium, we conclude that this current is the same $I_{\mathrm{K} 1}$ 
A

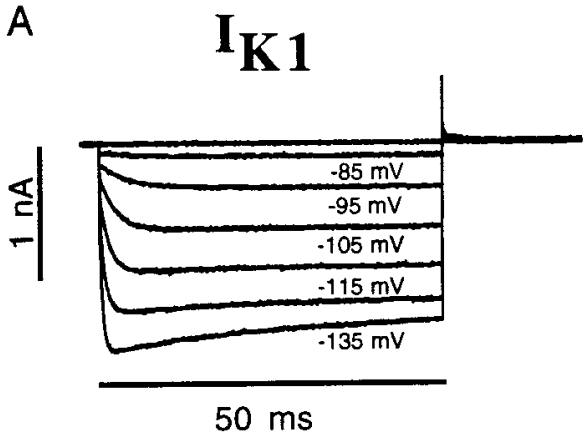

B

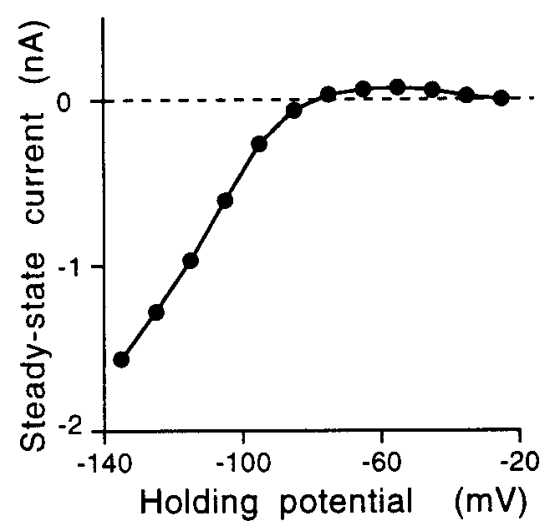

Figure 9. The inward-rectifying potassium current $I_{\mathrm{K} 1}$. $A$, In caudal hair cells and some medial hair cells, hyperpolarization of the membrane potential evoked a large and fast-activating current, which reversed polarity around $E_{\mathrm{K}}$. With greater levels of hyperpolarization, this current exhibited some inactivation, as seen here in the step to $-135 \mathrm{mV}$. $B$, This steady-state $I-V$ curve for $I_{\mathrm{K} 1}$ was determined for a caudal cell bathed in $2 \mathrm{mM} \mathrm{CdCl}_{2}$, which would reliably remove all other ionic currents active within this voltage range. The current first appears as an outward (positive) current at potentials negative to $-30 \mathrm{mV}$ and becomes inward (negative) below $-80 \mathrm{mV}$.

described in hair cells of the leopard frog sacculus (Holt and Eatock, 1995) and at least very similar to the $I_{\mathrm{IR}}$ of turtle BP hair cells (Goodman and Art, 1996b).

\section{The distribution of $I_{A}$ and $I_{K 1}$ implies overlapping populations}

The distributions of $I_{\mathrm{K} 1}$ and $I_{\mathrm{A}}$ in AP hair cells presented in Table 2 make it clear that these two populations are not entirely separate but rather appear to comingle within the medial portion of the AP. Figure 10 shows the percent distribution of $I_{\mathrm{A}}$ and $I_{\mathrm{K} 1}$ as a function of cell size in the AP (included as a measure of the likelihood of a hair cell of a particular size possessing either of these currents but distinct from variations in current amplitude). Two separate but overlapping populations emerge from this figure. Surprisingly, each current appears to be present along the full length of the epithelium. Experimental records support the observation that the largest cells possessing $I_{\mathrm{K} 1}$ (14 and $15 \mathrm{pF}$ ) were indeed very tall hair cells $(>60 \mu \mathrm{m})$ and not simply bloated short hair cells, making it very unlikely that these cells came from anywhere but the rostral patch of the AP.

\section{Factors influencing resonant frequency}

Resonant frequency varies with cell morphology

To establish that hair cells are arranged tonotopically, we first examined the relationship between cell morphology and wholecell capacitance. Simmons et al. (1994) demonstrated that AP hair cell bodies become progressively shorter moving rostrocaudally, declining from $>60 \mu \mathrm{m}$ in rostral hair cells to $<20 \mu \mathrm{m}$ caudally, with most of the change occurring within the rostral half of the AP. Notably, they identified the hair cells at the center of the rostral region (and not the rostral-most hair cells) as the tallest. We also found the tallest hair cells were those isolated from the center of the rostral patch, and these had whole-cell capacitances as large as $20 \mathrm{pF}$. Consistent with a relationship between cell size and frequency, Lewis et al. (1982b) showed, while reporting an overall rostrocaudal frequency gradient in the primary fibers innervating the AP, that the lowest frequencies were found not at the rostral-most position but more toward the center of the rostral patch. Together, these reports and our observations suggest that frequency is not mapped strictly rostrocaudally in the AP but instead may follow a more "radial" organization, with the lowest frequencies originating near the center of the rostral patch. The majority of rostral hair cells exhibited whole-cell capacitances that ranged from 12 to $18 \mathrm{pF}$. Medial hair cells had values between 8 and $12 \mathrm{pF}$, and caudal hair cells ranged from 4 to $8 \mathrm{pF}$. Using measurements taken from photographs of previously recorded hair cells, we plotted cell body length versus the measured whole-cell capacitance (Fig. $11 A)$. Changes in cell body length are accurately reflected by cell capacitance measurements. The dashed line indicates the predicted cell capacitance for hair cell bodies of different lengths (not including estimates of bundle capacitance), using the mean cell body cross-sectional width of $14 \mu \mathrm{m}$ and assuming a standard value of membrane capacitance of $1 \mu \mathrm{F} / \mathrm{cm}^{2}$. In Figure $11 A$, most of the data points are slightly below the predicted line, which is most likely the result of the compensation circuitry of the amplifier consistently underestimating the true whole-cell capacitance (whole-cell capacitance and series resistance compensations were never $100 \%$ ). In addition to cell length differences, there were also noticeable variations in cell shape, which would affect the accuracy of the predicted length-capacitance relationship; some rostral hair cells were gourd-shaped, whereas others resembled simple cylinders. Shape variations disappeared as cells became shorter. In other preparations (most notably the turtle), a large gradient in stereovillar bundle length precludes the use of wholecell capacitances as an indicator of cell size. In the AP, however, the only reported gradient in bundle height is mediolateral and not rostrocaudal (Lewis and Li, 1975; Lewis, 1977); thus, a rostrocaudal gradient in cell capacitance is expected to occur independent of hair bundle architecture. We did not estimate the contributions of the hair bundle to the overall membrane capacitance, although we believe that this is one important source of the observed variations in cell capacitance within each region of the AP. We conclude that the cell capacitance measurements obtained at the beginning of each experiment are useful and reasonably accurate indicators of cell body length and therefore of the original position of the hair cells along the rostrocaudal axis of the AP.

Figure $11 B$ shows the variation in resonant frequencies with cell size in the rostral half of the AP. Despite the scatter in the data, this plot supports the conclusion that cell size decreases as resonant frequency increases and, therefore, that resonant frequency covaries with rostrocaudal position in the AP. This evidence of a tonotopic distribution of resonant frequencies underlies the assumption that electrical tuning contributes to frequency selectivity in the AP.

Offset resonant frequencies recorded at a common membrane potential of approximately $-53 \mathrm{mV}$ varied from $50 \mathrm{~Hz}$ in the 


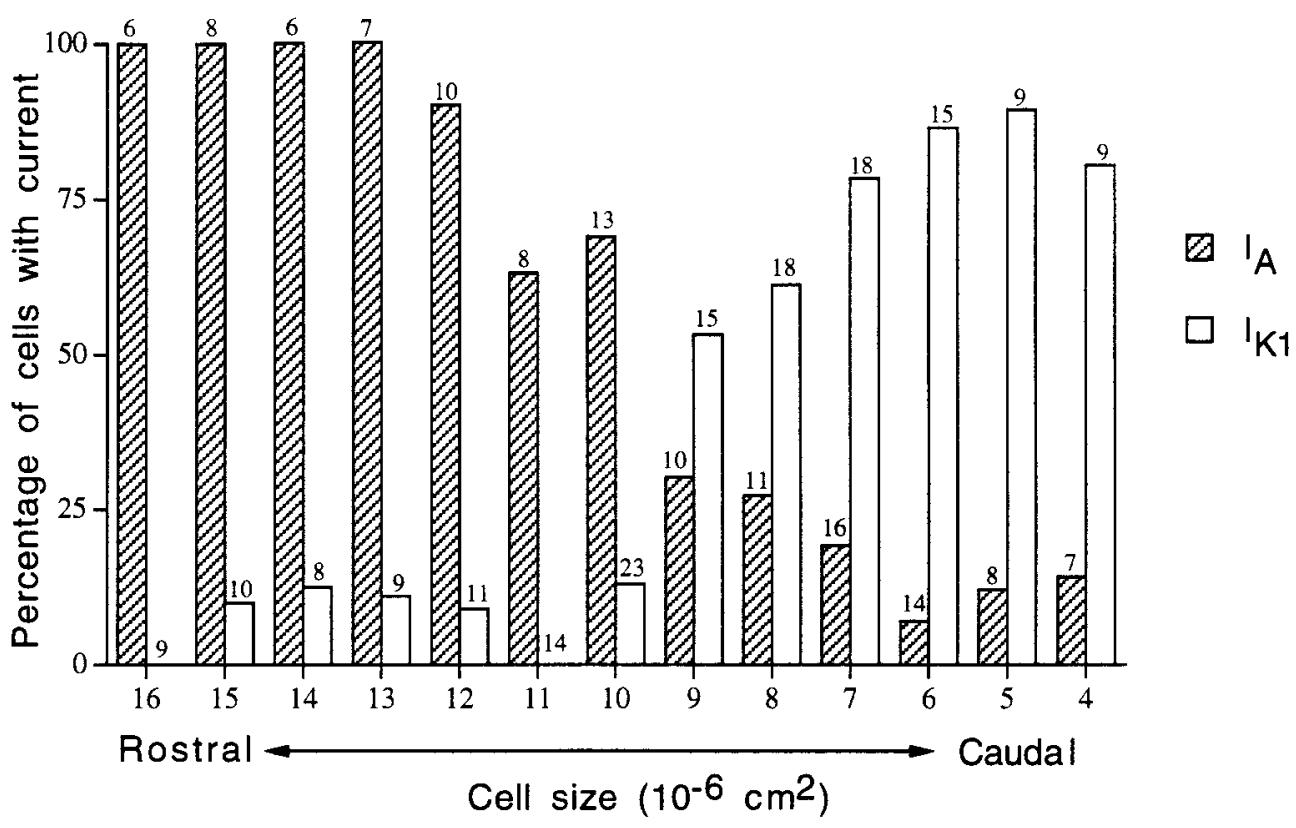

Figure 10. Distribution of $I_{\mathrm{A}}$ and $I_{\mathrm{K} 1}$. Using the protocols described in Figure 4, the presence or absence of $I_{\mathrm{A}}$ and $I_{\mathrm{K} 1}$ (independent of amplitude) was determined for cells of different sizes in the AP. An ionic current was considered present if its amplitude could be separated from the passive leak current and if it exhibited both time- and voltage-dependent kinetics matching those described for either $I_{\mathrm{A}}$ or $I_{\mathrm{K} 1}$. Bars represent the percentage of cells at each size found to possess a current, independent of amplitude. Some cells possess both currents. For $I_{\mathrm{A}}, n=124$; mean number of cells per bin, nine cells (minimum of 6); for $I_{\mathrm{K} 1}, n=168$; mean number of cells per bin, 13 cells (minimum of 8). The sample size $(n)$ is included above each bar. Cell size, given as the total membrane area calculated from whole-cell capacitance measurements, is directly proportional to cell height and has been shown to correspond to rostrocaudal position in the AP (see Results).

A

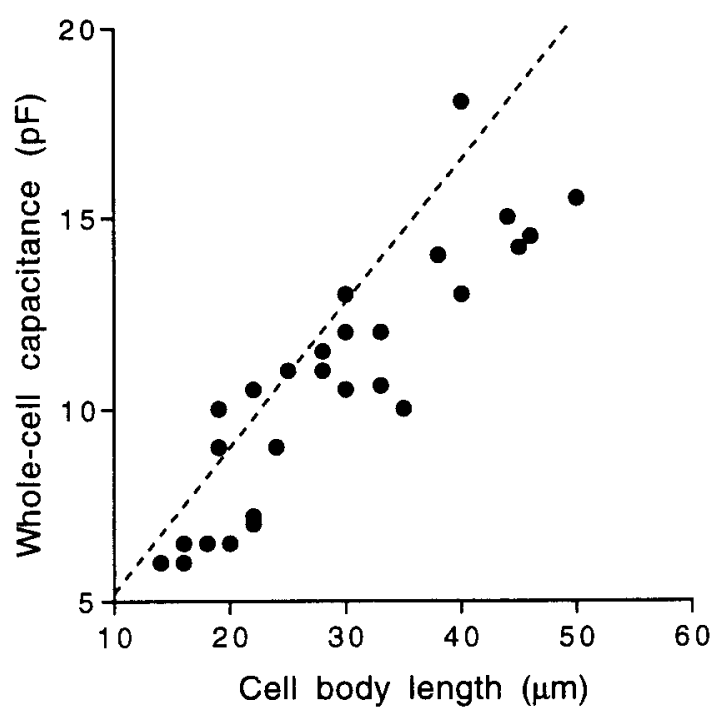

B

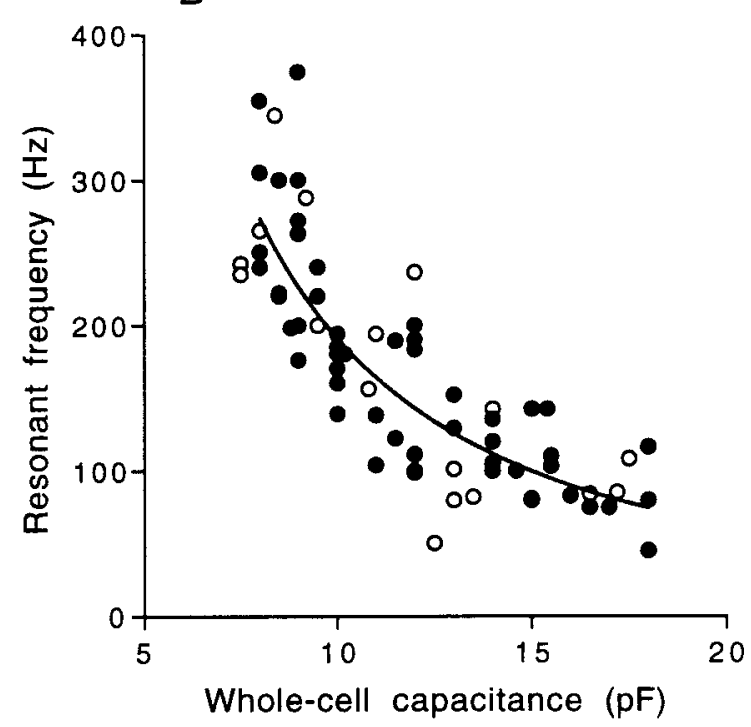

Figure 11. Resonant frequency changes with cell size. A, Whole-cell capacitance measurements are linearly related to hair cell body length. The dashed line is the predicted relationship between cell length and membrane capacitance, based on the mean AP hair cell cross-sectional diameter (14 $\mu$ m) and the standard for membrane capacitance $1 \mu \mathrm{F} / \mathrm{cm}^{2} . B$, Whole-cell capacitance (in picofaradays) is plotted against the resonant frequency of each hair cell at a common steady-state membrane potential of approximately $-53 \mathrm{mV}$ for cells isolated with papain ( filled circles). For most cells, this represented the highest $Q_{\mathrm{e}}$ oscillations, which were generated with small depolarizing current pulses. In some cases, the value included was taken from offset oscillations depending on the zero-current resting potential of the cell. Data were best fit using a least-squares algorithm by an equation of the form $y=$ $7700 \cdot x^{-1.6} ; \mathrm{r}^{2}=0.74 ; n=53$. Open circles represent data collected from hair cells isolated without using papain as a dissociative agent.

largest hair cells to $375 \mathrm{~Hz}$ in medial hair cells. Onset resonant frequencies were recorded to $475 \mathrm{~Hz}$. This range and distribution of resonant frequencies closely overlies the range of resonant frequencies recorded intracellularly in the AP by Pitchford and Ashmore (1987) and the known tonotopic map of the rostrome- dial AP (Lewis et al., 1982b). Afferent fibers innervating the medial AP have best frequencies at least as high as $600 \mathrm{~Hz}$, approximately twice the highest offset resonant frequencies observed in isolated hair cells. A similar inconsistency exists in the turtle cochlea in which the upper limit of resonant frequencies 
A
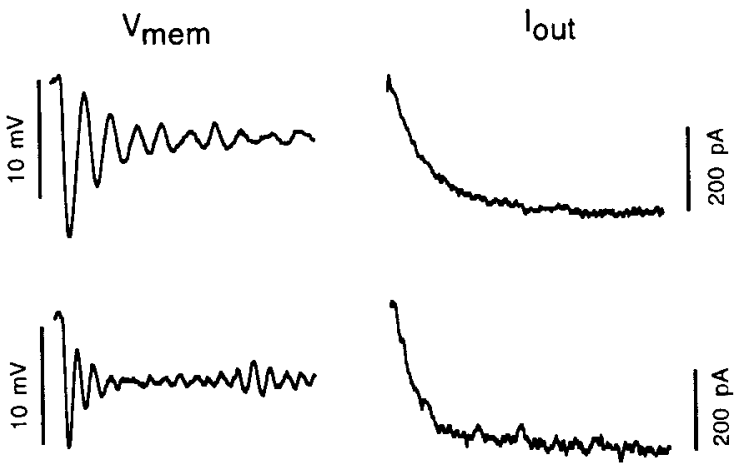

Figure 12. Resonant frequency changes with the time constant of the outward current. $A$, Offset resonant frequencies (recorded in current-clamp mode) oscillating at a common membrane potential of approximately $-53 \mathrm{mV}$ are presented on the left, along with their corresponding net outward tail currents on the right (recorded in voltage-clamp mode) at $-53 \mathrm{mV}$ after a 200 msec voltage step to $-30 \mathrm{mV}$. Holding potentials in current-clamp mode were maintained at approximately $-53 \mathrm{mV}$ with small standing currents. Offset oscillations followed a $100 \mathrm{pA}$ current pulse. The time constant of outward current relaxation $\left(\tau_{\mathrm{d}}\right)$ is progressively faster in higher frequency hair cells. Top, $100 \mathrm{~Hz} ; Q_{\mathrm{e}}$ of $6.5 ; \tau_{\mathrm{d}}$ of 6.0 msec; middle, $170 \mathrm{~Hz} ; Q_{\mathrm{e}}$ of $2.5 ; \tau_{\mathrm{d}}$ of 3.1 msec; bottom, $240 \mathrm{~Hz} ; Q_{\mathrm{e}}$ of $3.6 ; \tau_{\mathrm{d}}$ of 1.8 msec. $B$, Resonant frequency $\left(f_{\mathrm{o}}\right)$ at -53 $\mathrm{mV}$ is plotted against $\tau_{\mathrm{d}}$ at $-60 \mathrm{mV}$ after a $200 \mathrm{msec}$ step to $-30 \mathrm{mV}$. The data were well fit by an equation of the form $\tau_{\mathrm{d}}$ of $k / f_{\mathrm{o}}{ }^{2}$; $\left(k=24133.6 ; \mathrm{r}^{2}=0.88 ; n=33\right) . C$, Here, the inverse square root of the time constant is plotted against resonant frequency. Data fit with a straight line $(y=0.004 x+0.24$; $\left.\mathrm{r}^{2}=0.82\right)$. Open circles represent data collected from hair cells isolated without using papain as a dissociative agent. The dashed line represents the relationship reported for the turtle BP, taken from Art and Fettiplace, 1987. The turtle line is lower primarily because those tail currents were measured at potentials 10 to $20 \mathrm{mV}$ positive to the -60 $\mathrm{mV}$ used in our study of the AP.
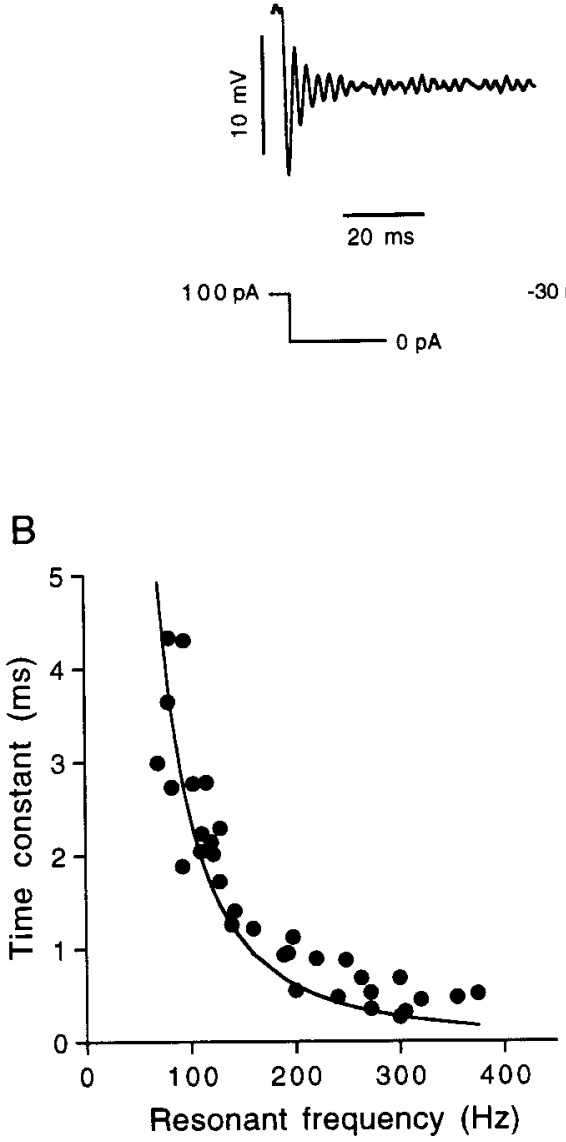

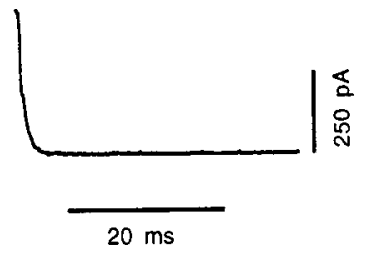

$-30 \mathrm{mV}$ recorded from hair cells in situ is approximately double that reported for isolated hair cells (Art and Fettiplace, 1987). The explanation suggested by Goodman and Art (1996a) for the turtle $\mathrm{BP}$ is that a reduction in resonant frequencies of isolated hair cells occurs as a result of a consistent reduction in the total number of ion channels during the dissociation procedure (Goodman and Art, 1996a). Armstrong and Roberts (1998) demonstrated that the use of papain as a dissociative agent appeared to increase the range of resonant frequencies observed in frog saccular hair cells. Given the potential pitfalls of enzymatic digestion, we isolated hair cells without the use of papain and investigated their electrical properties. In Figure $11 B$, the open circles represent "papain-free" hair cells. The relationship between cell capacitance and resonant frequency in the AP appeared to be unaltered by the use of papain.
Outward current kinetics mediate resonant frequency

In oscillatory AP hair cells, the majority of the outward current evoked from the cell resting potential is the calcium-dependent potassium current $I_{\mathrm{K}(\mathrm{Ca})}$. In the turtle basilar papilla, resonant frequency is strongly correlated with the kinetics of $I_{\mathrm{K}(\mathrm{Ca})}$ (Art and Fettiplace, 1987). Similarly, we found that the kinetics of the outward current changed systematically with resonant frequency in oscillatory AP hair cells. Figure $12 A$ provides three examples of offset resonant frequency of a hair cell (at $-53 \mathrm{mV}$; current clamp) and its corresponding outward tail current (at $-53 \mathrm{mV}$; voltage clamp). Hair cells with lower resonant frequencies had slower net outward tail currents, reflecting longer channel mean open times. The outward tail current was predominantly $I_{\mathrm{K}(\mathrm{Ca})}$, but as stated earlier, on average, $12 \%$ of the peak tail current in rostral hair cells could be eliminated by the addition of 4-AP, 
which was most likely caused by $I_{\mathrm{A}}$ contamination. Unlike Goodman and Art (1996a), however, no frequency-related variations in the relative contribution $I_{\mathrm{K}(\mathrm{Ca})}$ to the outward tail current were observed. Figure $12 \mathrm{~B}$ plots resonant frequency $(f)$ of a hair cell measured at a common steady-state membrane potential of -53 $\mathrm{mV}$ versus the outward tail current time constant $\left(\tau_{\mathrm{d}}\right)$ at a holding potential of $-60 \mathrm{mV}$ after a $200 \mathrm{msec}$ step to $-20 \mathrm{mV}$. In both the turtle basilar papilla (Crawford and Fettiplace, 1981; Art and Fettiplace, 1987) and the frog amphibian papilla, the relationship between $f$ and $\tau_{\mathrm{d}}$ appears well described by the function

$$
f^{2}=\left(\partial \mathrm{g} / \partial V_{\mathrm{m}}\left(V_{\mathrm{m}}-V_{\mathrm{r}}\right)\right) / 4 \pi^{2} C_{\mathrm{m}} \tau_{\mathrm{d}}
$$

which may be expressed as

$$
f=k \tau_{\mathrm{d}}^{-1 / 2}
$$

where $k$ is an empirically determined coefficient (Art et al., 1986; Art and Fettiplace, 1987; Wu et al., 1995) representing the relationship between conductance and membrane potential and also includes membrane capacitance. The data presented in Figure $12 \mathrm{~B}$ were well fit by Equation 3. The relationship becomes linear when resonant frequency is plotted against the inverse square root of the time constant (Fig. 12C). Also included in Figure 12C is the relationship between $f$ and $\tau_{\mathrm{d}}$ in turtle BP hair cells, taken from Art and Fettiplace (1987). The mild difference between the turtle and frog lines can probably be accounted for by (1) differences in the external calcium and potassium concentrations used, and (2) the holding potential at which $\tau_{\mathrm{d}}$ was measured; as mentioned above, we studied $\tau_{\mathrm{d}}$ at $-60 \mathrm{mV}$ and plotted it against $f$ at $-53 \mathrm{mV}$, whereas the data from the turtle were collected at the resting potential of each cell and therefore appear to have been typically in the range of -40 to $-50 \mathrm{mV}$ (Art and Fettiplace, 1987, their Figs. 1, 3-5). Because $\tau_{\mathrm{d}}$ becomes smaller with hyperpolarization (Art and Fettiplace, 1987), our tail current time constants are expected to be slightly less than those reported for the turtle over the same range of resonant frequencies and would therefore also have larger $\tau_{\mathrm{d}}{ }^{-1 / 2}$ values.

Again for the purposes of comparison, we examined the relationship between $f$ and $\tau_{\mathrm{d}}$ in papain-free hair cells, represented by the open circles in Figure 12C. Although the relationship between the outward current kinetics and resonant frequency appears virtually identical in the papain-free hair cells, some observations are worth mentioning. Our highest resonant frequencies and smallest $\tau_{\mathrm{d}}$ values were recorded from papain-dissociated hair cells, and the lowest resonant frequencies were recorded from papain-free hair cells, supporting the possibility that papain may be shifting the range of frequencies observed upward. However, the net effect on the overall range of frequencies and time constants observed is, if anything, small.

\section{$I_{C a}$ and $I_{K(\mathrm{Ca})}$ amplitudes vary with resonant frequency}

The electrical resonances in AP hair cells are driven by the interactions of the L-type, voltage-dependent calcium current $I_{\mathrm{Ca}}$ and the calcium-dependent potassium current $I_{\mathrm{K}(\mathrm{Ca})}$. After first recording the net outward current amplitude (in voltage-clamp mode) and the electrical resonance properties of the cell (in current-clamp mode), we used two separate methods to isolate and measure the amplitude of $I_{\mathrm{Ca}}$. In our first attempt to investigate the relationship between $I_{\mathrm{K}(\mathrm{Ca})}$ and $I_{\mathrm{Ca}}$ amplitudes and resonant frequency, we applied a combination of TEA and 4-AP to block $I_{\mathrm{A}}$ and $I_{\mathrm{K}(\mathrm{Ca})}$. Art and Fettiplace (1987) reported that this method produced unreliable measures of calcium current amplitude in turtle hair cells, and indeed, we found conflicting results using this combination of potassium channel blockers. There was a strong correlation between outward current amplitude and resonant frequency $\left(\mathrm{r}^{2}=0.82 ; n=14\right)$, but in the presence of TEA-4-AP, inward current amplitudes were not observed to change significantly with resonant frequency. To address the possibility that the TEA-4-AP cocktail was interfering with calcium current measures, we instead measured barium current amplitudes passing through the presumed voltagedependent calcium channel $\left(g_{\mathrm{Ca}}\right)$. Barium has been shown to pass through hair cell calcium channels more readily than calcium but does not activate $I_{\mathrm{K}(\mathrm{Ca})}$ (Art and Fettiplace, 1987; Fuchs et al., 1990; Zidanic and Fuchs, 1995). During initial experiments, it became clear that external barium alone was insufficient to guarantee the elimination of all outward currents; in low-frequency cells in particular, there was consistent evidence of either $I_{\mathrm{A}}$ or $I_{\mathrm{K}}$ contamination. Therefore, barium currents were recorded in 5 $\mathrm{mm}\left[\mathrm{Ba}^{2+}\right]_{\text {ext }}$ to which $10 \mathrm{~mm} 4$-AP was added. This combination appeared to provide the most reliable measure of inward current amplitudes; we found no evidence of inactivating outward currents under these conditions.

Under these conditions, peak $I_{\mathrm{Ba}}$ was observed to increase smoothly with resonant frequency in oscillatory hair cells (Fig. $13 A$ ) over the recorded frequency range of $\sim 300 \mathrm{~Hz}$. Furthermore, plotting this distribution alongside the data presented for hair cells of the turtle basilar papilla (Fig. 13A, turtle data taken from Art and Fettiplace, 1987) demonstrates a close similarity between the two preparations in this regard.

As mentioned above, outward current amplitude was also observed to increase with resonant frequency in oscillatory hair cells. Figure $13 B$ plots $g_{\mathrm{K}(\mathrm{Ca})}$ amplitude versus resonant frequency. The conductances included in Figure $13 B$ were believed to be almost exclusively $g_{\mathrm{K}(\mathrm{Ca})}$ based on the observation that the values included here were noninactivating steady-state currents and were mostly blocked by TEA, Ibtx, or barium; however, it cannot be ruled out that some voltage-dependent $\mathrm{K}^{+}$conductances contributed to these values.

\section{DISCUSSION}

\section{Two hair cell subtypes in the amphibian papilla}

There are two experimentally distinctive populations of hair cells in the amphibian papilla: an oscillatory-type electrically tuned hair cell that dominates the low- to mid-frequency auditory range of the AP, and a nonoscillatory cell type that dominates the midto high-frequency region of the AP. Those hair cells exhibiting prominent electrical resonances were more likely to possess $I_{\mathrm{A}}$ than $I_{\mathrm{K} 1}$, whereas the opposite was true for those hair cells, predominantly the caudal ones, not exhibiting high $Q_{\mathrm{e}}$ resonances.

A similarly bisected epithelial pattern in hair cell biophysics was also reported for the goldfish sacculus (Sugihara and $\mathrm{Fu}-$ rukawa, 1989) and chick BP (Fuchs and Evans, 1990), but the quality and frequency range of the resonances observed in those two preparations fall far short of the resonances described in turtle BP hair cells. The frog AP is unique then, in that it displays an epithelial organization similar to both fish and birds, and yet also exhibits most of the specializations of the electrically tuned turtle hair cells. With mounting evidence that the AP also possesses mechanical tuning mechanisms (Lewis et al., 1982a; Hillery and Narins, 1984; Stiebler and Narins, 1990), the AP becomes an ideal organ for investigating the evolution of electrical and mechanical tuning in terrestrial vertebrates. 
A

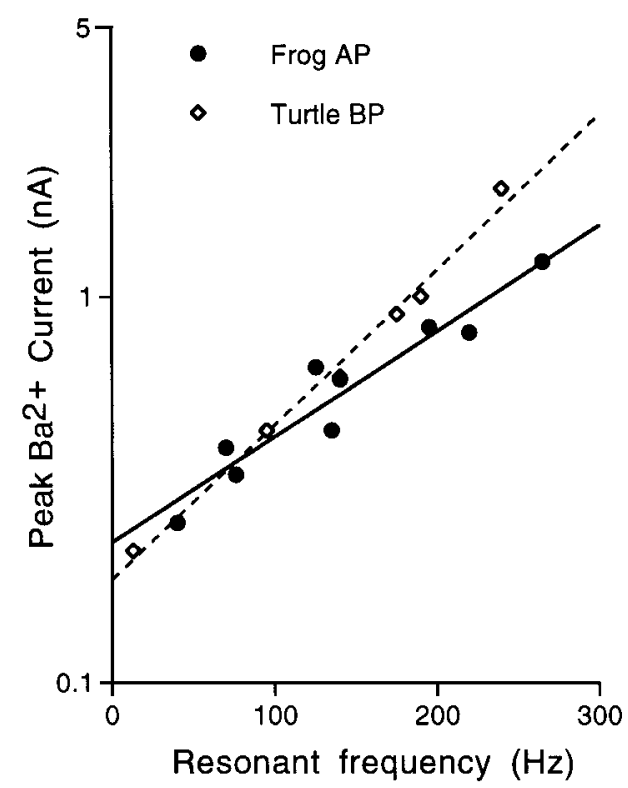

B

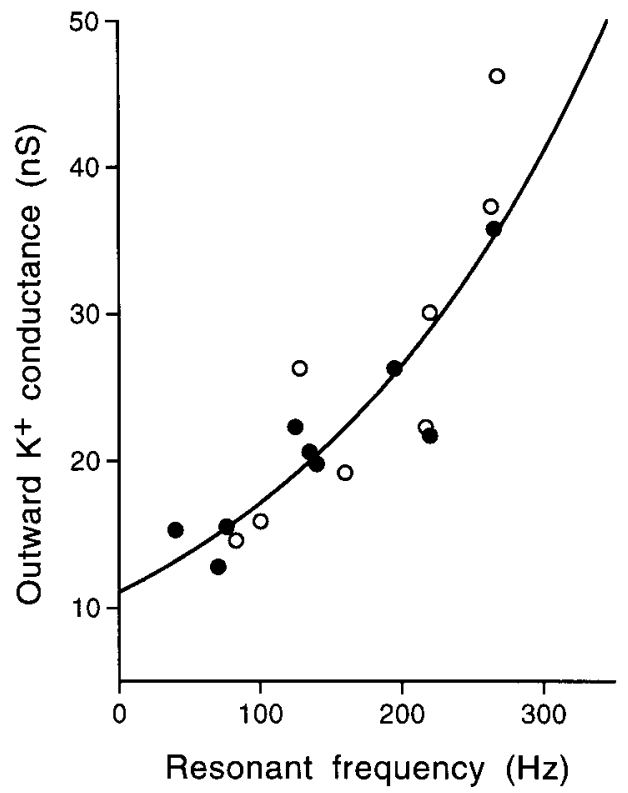

Figure 13. Current amplitudes increase with resonant frequency. $A$, Peak inward current was determined for oscillatory hair cells in an external medium containing $5 \mathrm{~mm}\left[\mathrm{Ba}^{+2}\right]_{\text {ext }}$ and $10 \mathrm{~mm} 4$-AP, after first recording their resonant frequency at $-53 \mathrm{mV}$ in control solution (standard internal pipette solution). Peak barium currents occurred at approximately a mean potential of $-23 \pm 3 \mathrm{mV}$ and were observed to be larger in hair cells exhibiting higher resonant frequencies. The data are plotted on a semi-log scale along with data for isolated hair cells of the turtle basilar papilla (open diamonds) taken from Art and Fettiplace (1987) to emphasize the similarities in $I_{\mathrm{Ba}}$ amplitude distribution exhibited by these two preparations. Both lines drawn by eye; solid line, frog AP; dotted line, turtle BP. B, Outward conductance amplitude, corrected for inward current amplitude, was calculated and plotted against the measured resonant frequency at $-53 \mathrm{mV}$. For the cells included from $A$, inward barium currents $(-20 \mathrm{mV})$ were divided by 2.5 (see Results) to provide an estimate of the calcium current amplitude, and this value was subtracted from the measured steady-state outward current at $-20 \mathrm{mV}$ to produce an estimate of the total outward current amplitude ( filled circles). In cells in which the calcium current was isolated using a TEA-4-AP cocktail (open circles), the calcium current amplitude at $-20 \mathrm{mV}$ was subtracted directly from the outward current amplitude at $-20 \mathrm{mV}$. Both sets of data produce a similar description of the rise in $g_{\mathrm{K}(\mathrm{Ca})}$ amplitude with resonant frequency. Conductances rather than currents are presented here to correct for differences in external $\mathrm{K}^{+}$concentrations; barium current experiments were performed in $5 \mathrm{mM}\left[\mathrm{K}^{+}\right]_{\mathrm{ext}}$, and the TEA-4-AP experiments were performed in $2 \mathrm{~mm}\left[\mathrm{~K}^{+}\right]_{\text {ext }}$. Curve fit by eye.

Our observation that rostral, but not caudal, hair cells are electrically tuned is consistent with neurophysiological data. Electrical tuning in the rostral half of the AP is supported by the highly temperature-sensitive tuning properties of the afferent fibers innervating the rostral but not caudal region (CFs exhibiting $Q_{10 \text { (temp) }}$ values at approximately 2.0) (Stiebler and Narins, 1990; Van Dijk et al., 1990), which implies that the temperaturesensitive ion channels are contributing substantially to frequency selectivity (Smolders and Klinke, 1984; Schermuly and Klinke, 1985; Wu et al., 1995). Other differences in the response properties of rostral and caudal AP afferent fibers are consistent with two separate auditory processing mechanisms. Ronken (1991) demonstrated that AP afferent fibers could be divided into two populations based on $W_{10} \mathrm{~dB}$ (tuning curve bandwidth $10 \mathrm{~dB}$ above threshold at $\mathrm{CF}$ ) and $Q_{10 \mathrm{~dB}}$ (the frequency at the lowest threshold divided by $W_{10 \mathrm{~dB}}$ ). Fibers with CFs below $\sim 600 \mathrm{~Hz}$ have higher $Q_{10} \mathrm{~dB}$ values and narrower $W_{10} \mathrm{~dB}$ values. Lowfrequency fibers have been reported to have lower thresholds and higher spontaneous rates (Frishkopf and Goldstein, 1963; Narins, 1987), and only low-frequency fibers are suppressible, exhibiting both one- and two-tone suppression (Feng et al., 1975; Christensen-Dalsgaard and Jorgensen, 1996).

Several lines of anatomical evidence support the recognition of two hair cell subtypes in the frog AP. Simmons et al. (1994) described two morphologically distinct groups of rostral and caudal hair cells in the leopard frog AP. Wever (1973) also divided the AP into anterior (rostral) and posterior (caudal) regions based on cell and cell nuclei morphology. Innervation patterns in the AP also suggest two populations. Thicker afferent fibers innervate the rostral AP, and these terminate on more hair cells than caudal afferents (Lewis et al., 1982b; Simmons et al., 1992). Efferent fibers only extend to the rostral region of the AP (Simmons et al., 1992).

Our failure to record electrical resonances in caudal AP hair cells may be the result of a preferential sensitivity to the enzymatic dissociation procedure. Hair cell electrical properties are almost surely modified by the dissociation procedure (Art and Fettiplace, 1987; Goodman and Art, 1996a; Armstrong and Roberts, 1998). Additionally, patch-clamp recording conditions become compromised as the size of the target cell is reduced, making it more likely that caudal cells will exhibit degraded electrical properties. Furthermore, the considerable resting conductance $\left(I_{\mathrm{K} 1}\right)$ in caudal hair cells has the potential to diminish $Q_{\text {e }}$ and could in effect "squelch" electrical resonances in isolated caudal hair cells. Thus, the absence of electrical resonances cannot by itself eliminate the potential for caudal hair cells to contribute to acoustic tuning.

\section{The role of $I_{A}$ in auditory hair cells}

In the AP, $I_{\mathrm{A}}$ is generally restricted to oscillatory hair cells in the low-frequency range of the AP. The $I_{\mathrm{A}}$ described here appears identical to the $I_{\mathrm{A}}$ described in chick BP hair cells (Murrow, 1994), and its distribution is qualitatively similar as well. In both the frog AP (Simmons et al., 1992) and the chick BP (Murrow and 
Fuchs, 1990; Murrow, 1994), $I_{\mathrm{A}}$ is present in oscillatory-type hair cells that receive efferent innervation. Efferent innervation has been shown to hyperpolarize frog saccular hair cells by as much as $20 \mathrm{mV}$ (Ashmore and Russell, 1982). Just such a hyperpolarization would release nearly $100 \%$ of $I_{\mathrm{A}}$ from its steady-state inactivation, and after succeeding depolarizations, the addition of the A-current would increase the outward current, diminishing the amplitude of the receptor potential. Similar to what was proposed for the chick (Murrow and Fuchs, 1990), we suspect $I_{\mathrm{A}}$ may act in conjunction with efferent inhibition to either suppress or modulate the time course of the receptor potential in hair cells of the rostral AP.

\section{Contributions of $I_{K 1}$ to the receptor potential}

Two potential contributions of the inward rectifier to the electrical response properties of hair cells have been described recently. First, the presence of $I_{\mathrm{K} 1}$ tends to hyperpolarize hair cell resting potentials in vitro (Holt and Eatock, 1995); it is unknown whether or not this effect occurs in vivo. Second, the relaxation of $I_{\mathrm{K} 1}$ at the initiation of the voltage response might provide positive feedback during the depolarizing phase of the voltage response. In the turtle, this was shown to enhance the quality of electrical tuning at the lowest frequencies (Goodman and Art, 1996b), but in that preparation, $I_{\mathrm{K} 1}$ disappears well below the frequency range at which it is found in the AP. In the frog AP, we find that $I_{\mathrm{K} 1}$ is generally restricted to highest frequency range of the epithelium. The distribution of $I_{\mathrm{K} 1}$ in the AP is more reminiscent of the chick BP than the turtle BP. In both the frog AP and chick BP (Murrow, 1994), $I_{\mathrm{K} 1}$ is found in nonoscillatory hair cells and is generally restricted to those cells that do not possess $I_{\mathrm{A}}$. The kinetics of $I_{\mathrm{K} 1}$ (typical deactivation time constants exceed 2.0 msec at $-55 \mathrm{mV}$ ) are slow enough to make it potentially detrimental to electrical tuning at frequencies above $500 \mathrm{~Hz}$. Additionally, the presence of $I_{\mathrm{K} 1}$ in the frog sacculus (Hudspeth and Lewis, 1988; Holt and Eatock, 1995), caudal AP, and BP (Smotherman and Narins, 1999) make it difficult to envision a consistent electrical tuning function for $I_{\mathrm{K} 1}$ in situ. The role of $I_{\mathrm{K} 1}$ in frog auditory hair cells remains an enigma.

\section{Resonant frequency is determined by multiple factors}

The range of resonant frequencies observed in the frog AP can be accounted for by three factors: whole-cell capacitance, current amplitudes, and outward current kinetics. Reducing the total area of basolateral membrane while increasing conductance amplitudes (and conductance density) produces lower input impedances and smaller membrane time constants, which speeds up the rate at which the membrane potential can fluctuate. The inward calcium current is increased, and the outward calcium-dependent potassium current becomes larger and faster to produce higher resonant frequencies. The result of these combined cellular changes is an array of hair cells that exhibit resonant frequencies ranging from 50 to $\sim 400 \mathrm{~Hz}$. For these hair cells, the predominant outward current flows through the BK-type calciumdependent potassium channel, and a thorough investigation in the turtle cochlea has provided us with considerable insight into the molecular mechanisms by which the kinetics of this channel are manipulated (Art et al., 1995; Wu et al., 1995). It appears that the role of this ion channel is similar for the frog and turtle in mediating electrical tuning, and the pattern of expression of this ion channel plays a large part in establishing the map of resonant frequencies within each sensory epithelium. The range of resonant frequencies observed appears similar for the frog and turtle, yet the acoustic frequency range of the AP is twice that of the turtle BP. Analytical modeling based on the properties of ion channels in turtle hair cells (Wu et al., 1995) has been used to demonstrate that it would be possible to extend electrical tuning up to several kilohertz, but the necessary physiological parameters have not yet been uncovered in any preparation.

\section{Effect of papain on hair cell electrical properties}

Armstrong and Roberts (1998) reported that papain digestion caused an alteration of the electrical resonance properties in frog saccular hair cells. The alterations were the result of papain (1) selectively removing a voltage-dependent potassium current $\left(I_{\mathrm{K}}\right)$ in some cells, and (2) speeding up the kinetic properties of $I_{\mathrm{K}(\mathrm{Ca})}$. In our investigations, we did not observe a significant $I_{\mathrm{K}}$ in AP hair cells dissociated without papain, and we have recently characterized an $I_{\mathrm{K}}$ in papain-dissociated hair cells of the frog BP (Smotherman and Narins, 1999). We did not test the effects of papain on $I_{\mathrm{K}(\mathrm{Ca})}$ kinetics directly. Papain is not expected to change the relationship between the outward tail-current timeconstant and resonant frequency, but it might cause a shift in the range of resonant frequencies observed. Our results could not rule out the suggestion that papain might speed up $I_{\mathrm{K}(\mathrm{Ca})}$, but we saw little change in the overall range of resonant frequencies, and the correlation between cell size and resonant frequency was papain-insensitive.

\section{REFERENCES}

Armstrong CE, Roberts WM (1998) Electrical properties of frog saccular hair cells: distortion by enzymatic dissociation. J Neurosci 18:2962-2973.

Art JJ, Fettiplace R (1987) Variation of membrane properties in hair cells isolated from the turtle cochlea. J Physiol (Lond) 385:207-242.

Art JJ, Crawford AC, Fettiplace R (1986) Electrical resonance and membrane currents in turtle cochlear hair cells. Hear Res 22:31-36.

Art JJ, Fettiplace R, Wu Y-C (1993) The effects of low calcium on the voltage-dependent conductances involved in tuning of turtle hair cells. J Physiol (Lond) 470:109-126.

Art JJ, Wu Y-C, Fettiplace R (1995) The calcium-activated potassium channels of turtle hair cells. J Gen Physiol 105:49-72.

Ashmore JF, Russell IJ (1982) Effect of efferent nerve stimulation on hair cells of the frog sacculus. J Physiol (Lond) 329:25P-26P.

Assad JA, Sheppard GMG, Corey DP (1991) Tip-link integrity and mechanical transduction in vertebrate hair cells. Neuron 7:985-994.

Bernard C, Ferrary E, Sterkers O (1986) Production of endolymph in the semicircular canal of the frog Rana esculenta. J Physiol (Lond) 371:17-28.

Christensen-Dalsgaard J, Jorgensen MB (1996) One-tone suppression in the frog auditory nerve. J Acoust Soc Am 100:451-457.

Crawford AC, Fettiplace R (1981) An electrical tuning mechanism in turtle cochlear hair cells. J Physiol (Lond) 312:377-412.

Eatock RA, Saeki M, Hutzler MJ (1993) Electrical resonances of isolated hair cells does not account for acoustic tuning in the free-standing region of the alligator lizard's cochlea. J Neurosci 13:1767-1783.

Feng AS, Narins PM, Capranica RR (1975) Three populations of primary auditory fibers in the bullfrog (Rana catesbeiana): their peripheral origins and frequency sensitivities. J Comp Physiol 100:221-229.

Fenwick EM, Marty A, Neher E (1982) A patch-clamp study of bovine chromaffin cells and of their sensitivity to acetylcholine. J Physiol (Lond) 331:577-597.

Frishkopf LS, Goldstein MH (1963) Responses to acoustic stimuli from single units in the eighth nerve of the bullfrog. J Acoust Soc Am 35:1219-1228.

Fuchs PA, Evans MG (1990) Potassium currents in hair cells isolated from the cochlea of the chick. J Physiol (Lond) 429:529-551.

Fuchs PA, Nagai T, Evans MG (1988) Electrical tuning in hair cells isolated from the chick cochlea. J Neurosci 8:2460-2467.

Fuchs PA, Evans MG, Murrow BW (1990) Calcium currents in hair cells isolated form the cochlea of the chick. J Physiol (Lond) 429:553-568.

Galvez A, Gimenez-Gallego G, Reuben JP, Roy-Contancin L, Feigenbaum P, Kaczorowski GJ, Garcia ML (1990) Purification and charac- 
terization of a unique, potent, peptidyl probe for the high conductance calcium-activated potassium channel from venom of the scorpion Buthus tamulus. J Biol Chem 265:11083-11090.

Goodman MB, Art JJ (1996a) Variations in the ensemble of potassium currents underlying resonance in turtle hair cells. J Physiol (Lond) 497:395-412.

Goodman MB, Art JJ (1996b) Positive feedback by a potassiumselective inward rectifier enhances tuning in vertebrate hair cells. Biophys J 71:430-442.

Hamill OP, Marty A, Neher E, Sakmann B, Sigworth FJ (1981) Improved patch-clamp techniques for high-resolution current recording from cells and cell-free membrane patches. Pflügers Arch 391:85-100.

Hillery CM, Narins PM (1984) Neurophysiological evidence for a travelling wave in the amphibian inner ear. Science 225:1037-1039.

Holt JR, Eatock RA (1995) Inwardly rectifying currents of saccular hair cells from the leopard frog. J Neurophysiol 73:1484-1501.

Hudspeth AJ, Lewis RS (1988) Kinetic analysis of voltage- and iondependent conductances in saccular hair cells of the bullfrog, Rana catesbeiana. J Physiol (Lond) 400:237-274.

Kaczorowski GJ, Knaus HG, Leonard RJ, McManus OB, Garcia ML (1996) High-conductance calcium-activated potassium channels; structure, pharmacology, and function. J Bioenerg Biomembr 28:255-267.

Lewis ER (1977) Structural correlates of function in the anuran amphibian papilla. Scanning Electron Microsc 2:429-436.

Lewis ER, Li CW (1975) Hair cell types and distributions in the otolithic and auditory organs of the bullfrog. Brain Res 83:35-50.

Lewis ER, Narins PM (1998) The acoustic periphery of amphibians: anatomy and physiology. In: Comparative hearing: fish and amphibians (Fay RR, Popper AN, eds), pp 101-154. New York: Springler.

Lewis ER, Leverenz EL, Koyama H (1982a) The tonotopic organization of the bullfrog amphibian papilla, an auditory organ lacking a basilar membrane. J Comp Physiol [A] 145:437-445.

Lewis ER, Baird RA, Leverenz EL, Koyama H (1982b) Inner ear: dye injection reveals peripheral origins or specific sensitivities. Science 215:1641-1643.

Murrow BW (1994) Position-dependent expression of potassium currents by chick cochlear hair cells. J Physiol (Lond) 480:247-259.

Murrow BW, Fuchs PA (1990) Preferential expression of transient potassium current $\left(\mathrm{I}_{\mathrm{A}}\right)$ by 'short' hair cells of the chick's cochlea. Proc R Soc Lond B Biol Sci 242:189-195.

Narins PM (1987) Coding of signals in noise by amphibian auditory nerve fibers. Hear Res 26:145-154.

Parsons TD, Lenzi D, Almers W, Roberts WM (1994) Calcium- triggered exocytosis and endocytosis in an isolated presynaptic cell: capacitance measurements in saccular hair cells. Neuron 13:875-883.

Pitchford S, Ashmore JF (1987) An electrical resonance in hair cells of the amphibian papilla of the frog Rana temporaria. Hear Res 27:75-83.

Roberts WM, Robles L, Hudspeth AJ (1986) Correlation between the kinetic properties of ionic channels and the frequency of membrane potential resonance in hair cells of the bullfrog. In: Auditory frequency selectivity (Moore BCJ, Patterson RD, eds), pp 89-95. New York: Plenum.

Ronken DA (1991) Spike discharge properties that are related to the characteristic frequency of single units in the frog auditory nerve. J Acoust Soc Am 90:2428-2440.

Schermuly L, Klinke R (1985) Change of characteristic frequency of pigeon primary auditory afferents with temperature. J Comp Physiol [A] 156:209-211.

Simmons DD, Bertolotto C, Narins PM (1992) Innervation of the amphibian and basilar papillae in the leopard frog: reconstructions of single labeled fibers. J Comp Neurol 322:191-200.

Simmons DD, Bertolotto C, Narins PM (1994) Morphological gradients in sensory hair cells of the amphibian papilla of the frog, Rana pipiens pipiens. Hear Res 80:71-78.

Smolders JWT, Klinke R (1984) Effects of temperature on the properties of primary auditory fibers of the spectacled caiman, Caiman crocodilus (L.). J Comp Physiol [A] 155:19-30.

Smotherman MS, Narins PM (1999) Potassium currents in auditory hair cells of the frog basilar papilla. Hear Res, 132:117-130.

Stiebler IB, Narins PM (1990) Temperature-dependence of auditory nerve response properties in the frog. Hear Res 46:63-82.

Su ZL, Jiang SC, Gu R, Yang WP (1995) Two types of calcium channels in bullfrog saccular hair cells. Hear Res 87:62-68.

Sugihara I, Furukawa T (1989) Morphological and functional aspects of two different types of hair cells in the goldfish sacculus. J Neurophysiol 62:1330-1343.

Van Dijk P, Lewis ER, Wit HP (1990) Temperature effects on auditory nerve fiber response in the American bullfrog. Hear Res 44:231-240.

Wever EG (1973) The ear and hearing in the frog, Rana pipiens. J Morphol 141:461-478.

Wu Y-C, Art JJ, Goodman MB, Fettiplace R (1995) A kinetic description of the calcium-activated potassium channel and its application to electrical tuning of hair cells. Prog Biophys Mol Biol 63:131-158.

Zidanic M, Fuchs PA (1995) Kinetic analysis of barium currents in chick cochlear hair cells. Biophys J 68:1323-1336. 